\title{
Distribution and Lipid Composition of Pandalus Shrimp Larvae in Relation to Hydrography in West Greenland Waters
}

\author{
Søren Anker Pedersen \\ Danish Institute for Fisheries Research, Department of Marine and Coastal Ecology \\ Kavalergården 6, DK-2920 Charlottenlund, Denmark
}

\begin{abstract}
The abundance and distribution of shrimp larvae were studied along four transects off West Greenland in June-July 1996. Zooplankton samples and vertical profiles of temperature, salinity, and fluorescence were obtained along the transects in order to relate larval distribution to hydrographical and biological characteristics. Eight species of shrimp larvae occurred in the samples; Pandalus montagui and Pandalus borealis were the most numerous constituting 61 and $29 \%$ of the larvae, respectively. Other species of shrimp larvae were, in declining order of abundance, Sabinea septemcarinata, Lebbeus groenlandicus, Spirontocaris spinus, Eualus galmardi, Pontophilus (norvegicus?), and Argis dentata. Pandalus shrimp larval density showed a significant positive association with mean fluorescence $(5-80 \mathrm{~m})$, but no association with mean temperature, or densities of copepod eggs and nauplii. However, most larvae were caught in water columns with temperatures and salinities of $\sim 2{ }^{\circ} \mathrm{C}$. and $\sim 33 \mathrm{psu}$, respectively. Abundance of $P$. montagui was negatively correlated with mean salinity and the proportion of $P$. montagui was higher in stations closest to the coast. Catches of $P$. montagui and $P$. borealis larvae were positively correlated $(r=0.729)$.
\end{abstract}

Analysis for lipid class composition in P. montagui and P. borealis zoea stage 3 and 4 revealed that phospholipids were the most abundant lipid class ( $\sim 80 \%$ of total lipid weight) followed by triacylglycerols (TAG) (10-15\%), and wax esters (3-6\%). TAG wet-weight ratios of $P$. montagui and $P$. borealis larvae were used as indices of feeding condition, and showed differences between larval species, zoeal stage, sampling station, and transect. In the same zoeal stage $P$. montagui larvae had higher TAG condition indices than $P$. borealis larvae suggesting that $P$. montagui may have a greater growth and survival potential. The TAG condition indices showed a significant negative association with fluorescence and indices of copepod productivity for stage $4 \mathrm{P}$. montagui larvae and no associations for $P$. borealis stage 3 and 4 larvae. Future studies should investigate lipid condition of the earliest stages of $P$. borealis and $P$. montagui larvae and establish trophic relationships (lipid nutrition) using food web tracer lipids. Such studies could be important to achieve better recruitment predictions for both species.

Key words: abundance, condition, distribution, larvae, lipid, shrimp, W. Greenland

\section{Introduction}

During the last 20 years the most important fishery resource in West Greenland waters has been the northern shrimp (Pandalus borealis). Annual landings of northern shrimp from West Greenland waters increased from $7000-8000$ tons in the early1970 s to close to 87000 tons in 1992, the highest level in the history of this fishery (Anon., 1997). Historically the shrimp fishery at West Greenland has taken place in two main areas (Carlsson, 1997): (1) the inshore shrimp fishery (inside the three-mile limit) at West Greenland, taking place mainly in the Disko Bay, but also in a number of fjords and along the West Greenland coastline, (2) the offshore West Greenland shrimp fishery, outside the three-mile limit. Today the fishing industry as well as the economy in Greenland is mainly dependent on this large northern shrimp fishery, based on stable recruitment of new year-classes to the shrimp stocks (Christensen and Vestergaard, 1993). However, knowledge of recruitment variability and its causes for the shrimp stocks at West Greenland and in other areas is sparse (Hvingel, 1997). 
Shrimp stock assessments require information on strength of recruiting year-classes as early as possible. Current forecasts of shrimp stock productivity and potential fishing yields are weak partly due to lack of knowledge of population processes from hatching until first capture in the fishery at about 4 years of age. Shrimp stocks may fluctuate between high and very low stock levels within only a few years (e.g. Gulf of Alaska and Gulf of Maine stocks). Other examples show sudden occurrence of new productive shrimp fishing grounds (e.g. the Flemish Cap fishery). Changes in hydrographical conditions (water temperature) have been described as a main factor for northern shrimp stock fluctuations (Shumway et al., 1985; Tande et al., 1994; Rasmussen and Tande, 1995). Year-class strength of fish and shellfish populations is mainly determined during the early life stages (Cushing, 1995). Fluctuations in both abiotic (e.g. sea temperature, water mass stability, hydrographic fronts) and biotic (e.g. food availability, predation) factors affect growth and survival of fish and shellfish larvae (e.g. Stein and Lloret, 1995; Munk et al., 1995; Ouellet et al., 1995; St. John and Lund, 1996).

According to Ouellet et al., $(1992,1995)$ a biochemical (lipid-based) condition index can reflect survival potential of $P$. borealis larvae. This may prove to be a powerful tool in assessing ecological factor(s) involved in recruitment processes of $P$. borealis populations. In high latitude areas, total lipid content of $P$. borealis, ranging from 10 to 52 months old, exhibits marked seasonal oscillations which are linked to the highly seasonal pelagic production cycle (Hopkins et al., 1993). In general little is known about the lipid composition and relative energetics of field collected Pandalid shrimp larvae (Clarke, 1979; Hopkins et al., 1993; Ouellet et al., 1995). The objectives of this study were: (1) to describe species, stage, size, and lipid composition of shrimp larvae along four sampling transects off the West Greenland coast, and (2) to relate larval distribution and lipid condition indices to hydrographical and biological characteristics observed along the transects.

\section{Materials and Methods}

\section{Study area and sampling}

A total of 53 stations spaced at 4,8 or 12 nautical miles along four transects off West Greenland were sampled from 26 June to 5 July 1996 with the $28 \mathrm{~m}$ Greenlandic research vessel Adolf Jensen (Fig. 1). Transects were placed across shelf areas where coastal water masses meet water of oceanic origin. The distance between station positions was short where hydrographic fronts might be established, enhancing productivity and larval aggregation (Munk et al., 1995). On all stations zooplankton were sampled using a MIK plankton sampler $(2 \mathrm{~m}$ diameter ringnet) equipped with a $16 \mathrm{~m}$ long black polyfile net of $1 \mathrm{~mm}$ mesh size. The basic design of the gear is illustrated in Munk (MS 1993). For stations 30 to 53 (the two southernmost transects) a Bongo plankton sampler (diameter $0.61 \mathrm{~m}$ ) equipped with 0.5 and $1 \mathrm{~mm}$-mesh monofile nets was also used. Zooplankton samples were obtained using depth integrated oblique tows to about $80 \mathrm{~m}$ (or to near the bottom) at a towing speed of about 3 knots. The volume filtered was determined using General Oceanics flowmeters. On each station a Sea-bird 25-01 sea logger CTD was used to obtain vertical profiles of temperature (SBE 3), salinity (SBE 4), and fluorescence (Chelsea). On every second station the density (in number per $\mathrm{m}^{3}$ ) of copepod eggs and nauplii in the upper $60 \mathrm{~m}$ was obtained from one vertical haul with a ringnet (22.5 $\mathrm{cm}$ diameter and $50 \mu \mathrm{m}$ mesh size) to provide indices of copepod productivity. At 16 stations, fresh Pandalus sp. larvae were randomly picked out of the samples and frozen individually in $20 \mathrm{~mm}$ glass tubes at $-25^{\circ} \mathrm{C}$ for later determination of lipid contents in the laboratory. Remaining organisms were preserved in $4 \%$ buffered formalin. Associations among temperature, salinity, fluorescence, indices of copepod productivity, and shrimp larval density (number per $\mathrm{m}^{2}$ ) were investigated by Spearman rank correlations. The number of shrimp larvae caught by the two Bongo nets was compared using Chi-square $\left(\chi^{2}\right)$ tests $(p \times q$ contingency tables $)$ (Campbell, 1975).

\section{Species, stage size and abundance of the shrimp larvae}

In the laboratory all shrimp larvae were sorted from the MIK and Bongo zooplankton samples. In samples containing more than 200 shrimp larvae, the sample was split so that a minimum of about 100 shrimp larvae were counted and identified to species. Shrimp larvae from most of the MIK hauls and from a few selected Bongo hauls (e.g. station 48 with no MIK sample) were identified to species and zoeal stage. Abundance estimates were standardized to number per square meter of sea surface to a sampling depth of $80 \mathrm{~m}$ or to the depth to bottom (over the Banks with depths less than $80 \mathrm{~m}$ ) (Smith and Richardson, 1977). The fresh and formalin preserved shrimp larvae were measured for 
PEDERSEN: Shrimp Larvae in West Greenland Waters

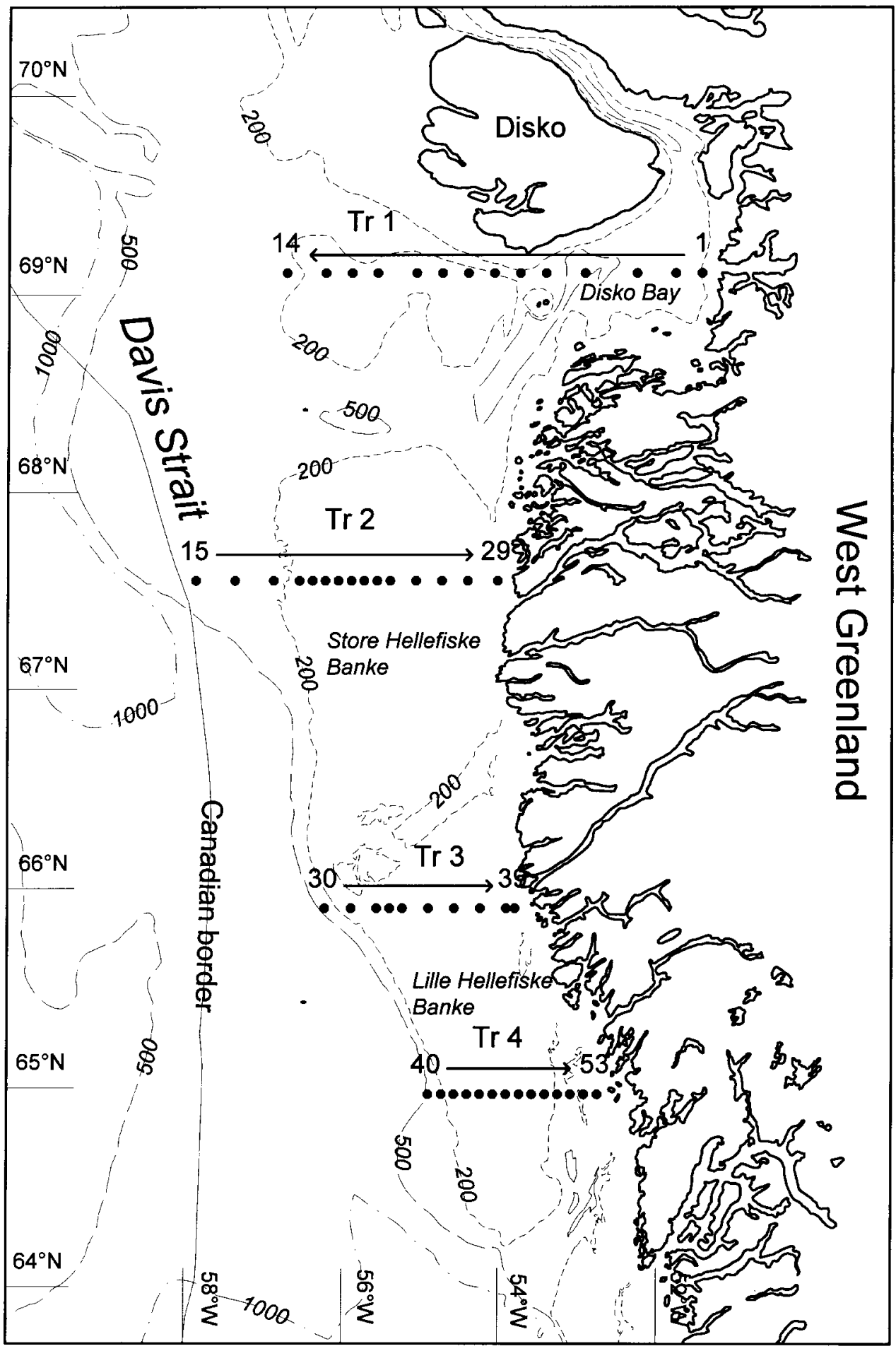

Fig. 1. Map showing transects and stations, direction of sampling, and the major physiographic features.

carapace length (posterior edge of orbit to middorsal posterior margin of carapace) and total length (tip of rostrum to end of telson) under a dissecting microscope with an optical micrometer. Multi-way and one-way analysis of variance (ANOVA) was used to test for differences between stations and 
transects in mean size by species and zoeal stage (Anon., 1985; GLM procedure).

Species and stage identifications of the shrimp larvae were based on the following: Pandalus borealis, Berkeley (1930), Haynes (1979, 1985), Squires (1993); Pandalus montagui, Pike and Williamson (1964), Squires (1993); Lebbeus groenlandicus, Haynes (1978), Squires (1993); Sabinea septemcarinata, Squires (1993); Other species, Squires (1993).

\section{Biochemical analysis and larvae condition}

A total of 162 randomly selected shrimp larvae (Pandalus borealis and P. montagui) from 12 stations were analyzed for lipid class composition (Table 1). The stations were selected along transects 3 and 4 (coast to offshore) to investigate variation in lipid content of the larvae in relation to changes in the environment (temperature, salinity and abundance of potential larval food). Larvae from one station on transect 2 were also included to test for possible south to north effects on the lipid contents.

Lipid extractions were performed on individual larvae for $2 \times 24$ hours in $2 \times 1 \mathrm{ml}$ chloroform/ methanol $(2: 1 \mathrm{v} / \mathrm{v})$ at $-20^{\circ} \mathrm{C}$ with a known quantity (ca. $45 \mu \mathrm{g}$ ) of Nonadecane added as an internal standard. After extraction the solvent was evaporated under a stream of argon-gas and the lipid extract was resuspended in $50 \mu \mathrm{l}$ of solvent. $1.4 \mu \mathrm{l}$ of the sample was then spotted on a SIII-Chromarod

TABLE 1. Number of shrimp larvae (N) analysed for lipid content by station. Pandalus borealis stage 3 and $4=\mathrm{Pb}-3$ and $\mathrm{Pb}-4$; Pandalus montagui stage 3 and $4=\mathrm{Pm}-3$ and Pm-4.

\begin{tabular}{|c|c|c|c|c|c|}
\hline \multicolumn{2}{|c|}{ Station no. $\mathrm{Pb}-3$} & \multirow{2}{*}{$\frac{\mathrm{Pb}-4}{\mathrm{~N}}$} & \multirow{2}{*}{$\frac{\mathrm{Pm}-3}{\mathrm{~N}}$} & \multicolumn{2}{|l|}{$\mathrm{Pm}-4$} \\
\hline & $\mathrm{N}$ & & & $\mathrm{N}$ & Sum \\
\hline 23 & 2 & & & & 2 \\
\hline 31 & 10 & 4 & & & 14 \\
\hline 36 & 1 & 1 & 4 & 5 & 11 \\
\hline 37 & 3 & 3 & & 9 & 15 \\
\hline 39 & 1 & 3 & & 16 & 20 \\
\hline 42 & 6 & 4 & & & 10 \\
\hline 43 & 1 & 14 & & & 15 \\
\hline 44 & 5 & 6 & & 4 & 15 \\
\hline 46 & 5 & 10 & & & 15 \\
\hline 49 & 2 & 9 & & 4 & 15 \\
\hline 50 & 6 & 7 & & 2 & 15 \\
\hline 53 & 2 & 4 & 1 & 8 & 15 \\
\hline Sum & 44 & 65 & 5 & 48 & 162 \\
\hline
\end{tabular}

for quantification using flame ionization detection with a model MK-5 IATROSCAN TLC/FID analyzer (Iatron, Inc., Japan). The rods were initially developed for $31 \mathrm{~min}$ in hexane - ethyl ether - formic acid (82:2.5:0.045, v/v/v, following Ouellet et al. 1992) allowing separation of the Nonadecane and the esters. Each rod was then developed for $28 \mathrm{~min}$ in hexane - ethyl ether - formic acid (55:29.7:0.075, v/v/v, following Ouellet et al., 1992) for separation of the sterol-ester (WAX), triacylglycerol (TAG), free fatty acid (FFA), and free sterol constituents (CHL). The polar lipids (phospholipids (PHO)) were quantified using an addition of a third chromarods development $(25 \mathrm{~min}$ in chloroform:methanol:water $(70: 30: 3.5, \mathrm{v} / \mathrm{v} / \mathrm{v})$. The quantification of each lipid constituent was based on calibration curves constructed from solutions of standard lipids. For each shrimp larva the analysis for lipids was run twice in order to minimize errors. In general an average of the two calculations of lipid contents was used, however, in a few cases only one of the calculations was within the normal range and reliable. The latter was mainly restricted to phospholipids and due to error in the quantification procedure. Wet weights (WW) and dry weights (DW, freeze-dried for 24 hours using CD52 (HETO)) were measured for each individual larva before and after lipid extractions to the nearest 0.01 and $0.005 \mathrm{mg}$, respectively. Hence, the dry weights were "lipid free" weight.

Lipid content (WAX, TAG, FFA, CHL and PHO) relative to wet and dry weight of individual larvae was investigated for variation among species, size, stage, sampling station and transect using multi- and one-way analysis of variance (ANOVA) (Anon., 1985; GLM procedure). Associations among fluorescence, indices of copepod productivity, larval density (number per $\mathrm{m}^{2}$ ) and TAG condition indices were investigated using Spearman rank correlations (Anon., 1985; CORR procedure).

\section{Results}

\section{Hydrography, fluorescence and indices of copepod productivity}

Temperature along the four transects showed a general increasing trend from north to south (Fig. 2 ). Cores of very cold water (below $-1^{\circ} \mathrm{C}$ ) were found at depths between 20 and $100 \mathrm{~m}$ in the Disko Bay area, on the western most stations close to the edge of the West ice on transect 1 , and on the 

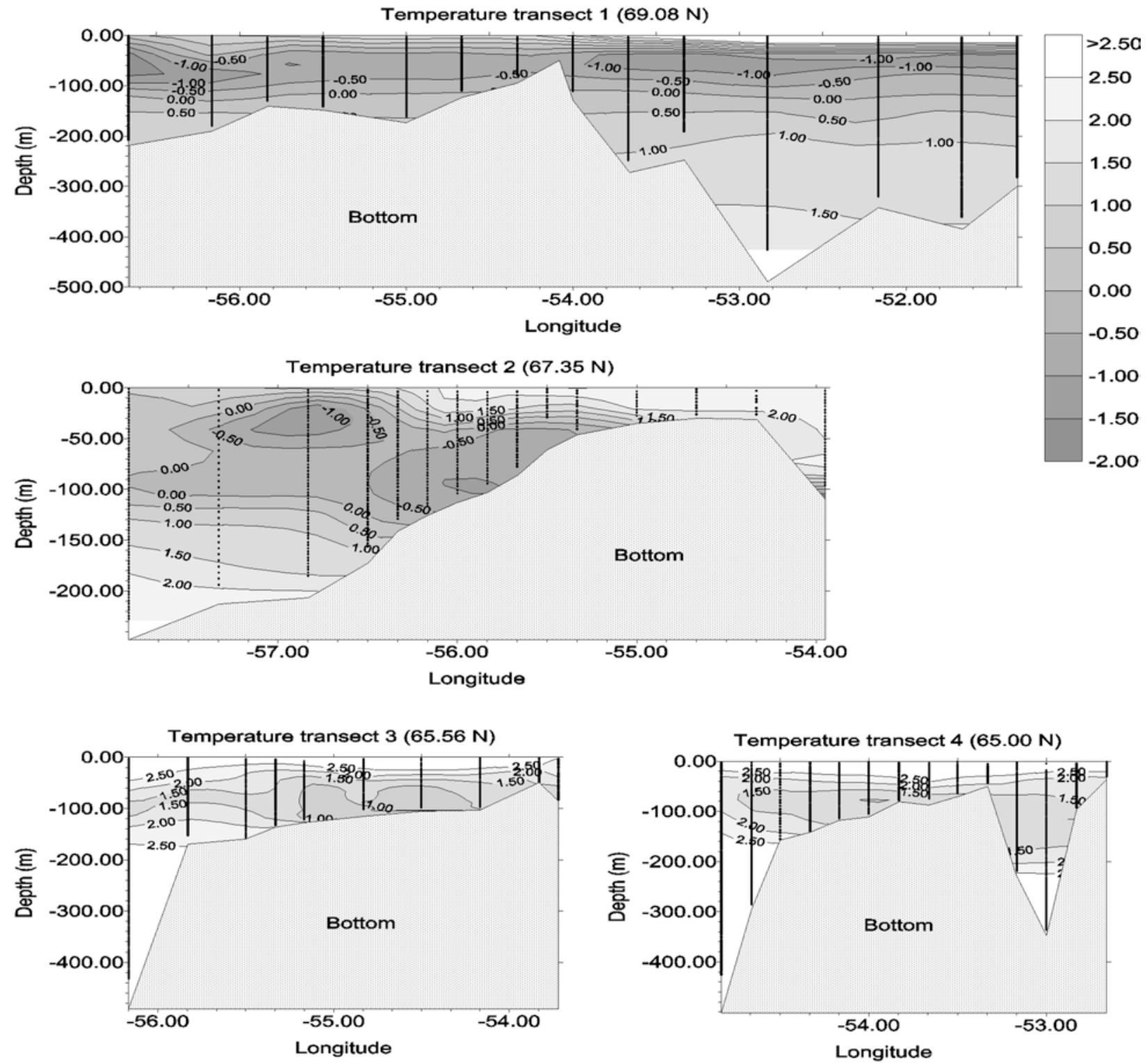

Fig. 2. Vertical sections of temperature $\left({ }^{\circ} \mathrm{C}\right)$ along transects $1-4$. Vertical lines indicate sampling stations and depths.

western slope of the shelf on transect 2. On transect 3 and 4 cores of cold water (from below 1 to $1.5^{\circ} \mathrm{C}$ ) were found at depths between 60 and $120 \mathrm{~m}$. The salinities varied from 32.0 to 34.7 psu with the lowest salinity levels in the surface layer of transects 1 and 2 and the highest in the bottom water layer at the western most stations of transect 3 and 4 (Fig. 3 ). The temperature and salinity profiles along the transects showed no or weak indices (transect 2 ) of frontal or upwelling zones (Fig. 2 and 3).
The fluorescence data indicate how primary productivity changed along and among the transects (Fig. 4). On transect 1 and 3 there were peaks in the fluorescence at about $40 \mathrm{~m}$ (range 20-60 m), whereas the peak was deeper at transect 2 (60 to $120 \mathrm{~m})$, and shallower at transect $4(0-40 \mathrm{~m})$. The mean fluorescence in the depth range 5-80 m differed significantly between stations and between transects (Fig. 4). Transect 1 generally showed the highest fluorescence although there were variations 

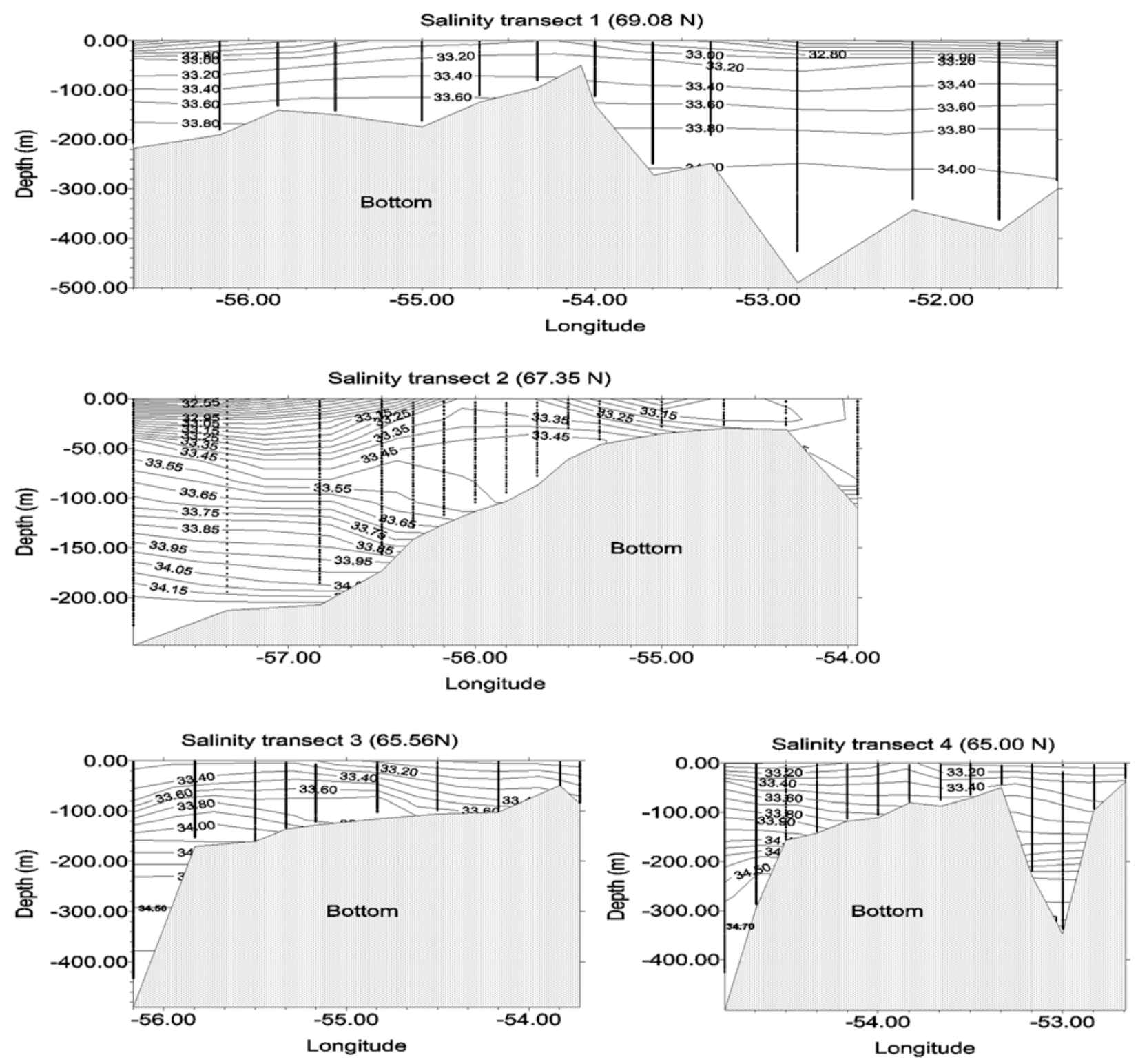

Fig. 3. Vertical sections of salinity (psu) along transects 1-4. Vertical lines indicate sampling stations and depths.

along the transect. Transects 2, 3 and 4 all showed the highest mean fluorescence on the station closest to the coast (Fig. 4). Densities of copepod eggs + nauplii ranged from about 50 to 7500 per $\mathrm{m}^{3}$ with no clear trend in abundance along or between transects (Peter Munk, unpubl. data). In addition, the ratio egg concentration/nauplii concentration at each sampling station was about 1:1 with no clear trends within or between transects There was no significant correlation between mean fluorescence (5$80 \mathrm{~m})$ and density of copepod eggs + nauplii $(n=$ 26, $r=0.28, p=0.16)$.

\section{Shrimp larval catches and abundances}

$M I K$. The estimated total number of shrimp larvae caught with the MIK plankton sampler was 9 737. The highest abundances of shrimp larvae were found on stations 38 and 39 with a total number per haul of 3454 and 4154, respectively. Large catches were also taken on stations 22, 23 and 24 with total numbers per haul of 274,753 and 248 , respectively. The shrimp larvae catches with the MIK sampler recalculated to number of shrimp larvae per $\mathrm{m}^{2}$ in the upper $80 \mathrm{~m}$ of the water column 
showed the same relationships (Fig. 4). Shrimp larval abundance was significantly correlated with mean flourescence $(5-80 \mathrm{~m})$ on transect $4(r=0.76$, $p=0.002$ ), but not on transects 2 and 3. Shrimp larval abundance showed no significant correlation with indices of copepod productivity (number of eggs + nauplii per $\mathrm{m}^{3}$ ), mean temperature or mean salinity $(5-80 \mathrm{~m})$.

Bongo. The total catch of shrimp larvae in the 24 Bongo hauls with $0.5 \mathrm{~mm}$ and $1 \mathrm{~mm}$ nets was
2234 and 3 317, respectively. The largest catches were taken on stations 37,38 and 39 and the number of shrimp larvae caught was 232, 596, $980(0.5 \mathrm{~mm}$ net), and 576, 883, 1486 (1 mm net), respectively. On transect 3 there was a significant difference $\left(\chi_{9}^{2}=31.7, p<0.1\right)$ between the two Bongo nets, the $1.0 \mathrm{~mm}$ net catching more shrimp larvae. However, on transect 4 the $0.5 \mathrm{~mm}$ net caught significantly $\left(\chi_{13}^{2}=28.6, p<0.1\right)$ more larvae than the $1.0 \mathrm{~mm}$ net. Compared with the MIK sampler, the Bongo sampler (both nets) had significantly higher
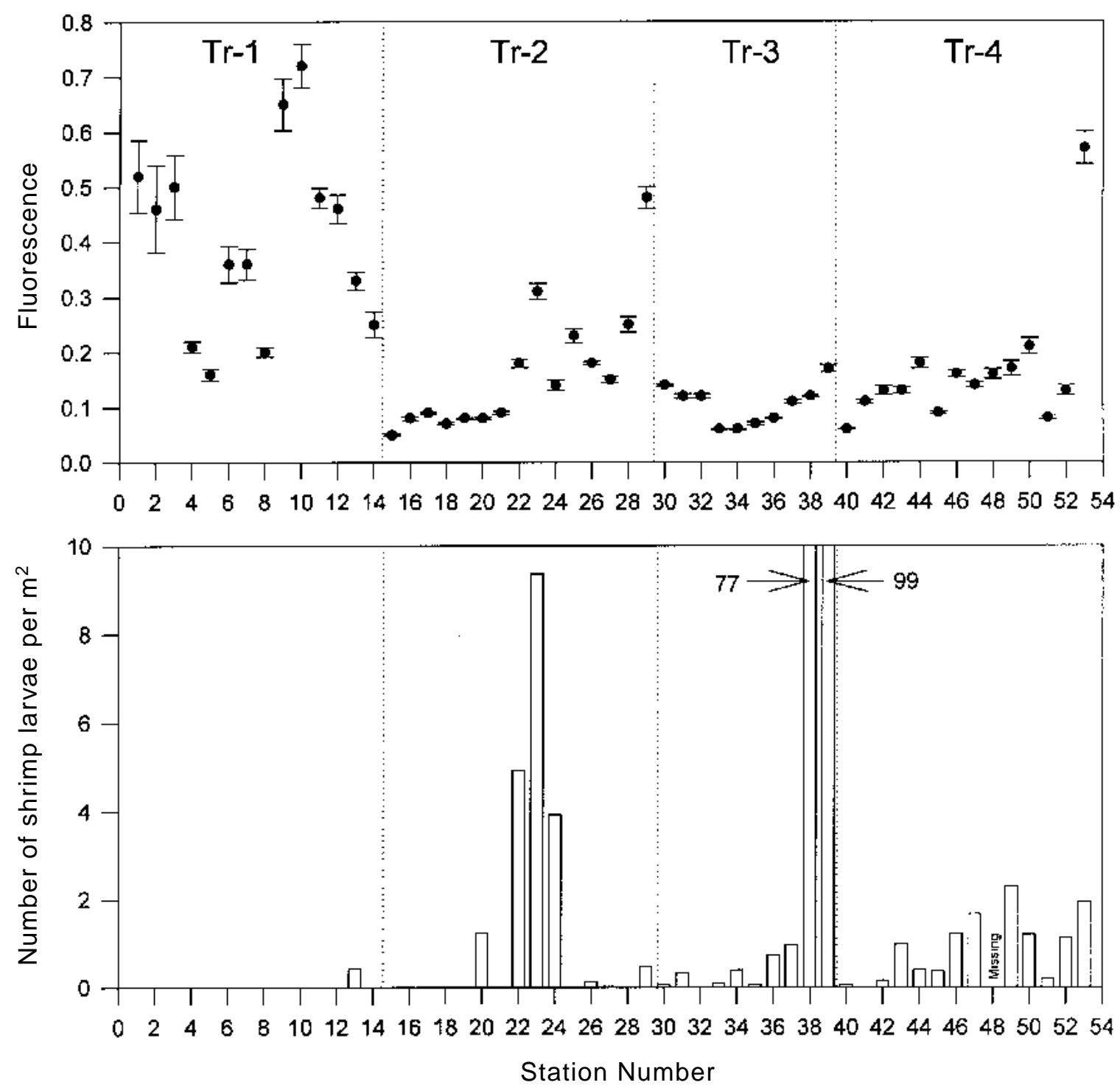

Fig. 4. Mean fluorescence with standard error of the mean (top), and shrimp larvae catches per $\mathrm{m}^{2}$ by the MIK plankton sampler (bottom) along transects 1-4. 
catches of shrimp larvae (on the order of 10 times as many). The difference between the samplers was best illustrated on transect 4 (Fig. 5). However, the catches of Bongo (mean of both nets) and MIK along transect 3 and 4 were significantly correlated ( $r=0.88$ and $r=0.64$, respectively), shows the same trends, and the largest catches by all three net types were taken on the stations closest to the coast.

\section{Species, stages and sizes of the shrimp larvae}

Nine species of shrimp larvae were caught with the MIK plankton sampler (Table 2). Pandalid larvae composed over $90 \%$ of the catch $(n=1278$ identified larvae). Most Pandalid larvae were in zoeal stages 3 and 4; however, zoeal stages from 2 to 5 were present. Length distributions by stage show two size groups in stages 3 and 4 (Fig. 6). For larvae in zoeal stage 3 there are peaks in the size distribution at carapace length 1.6, 1.8, 2.4 and $2.5 \mathrm{~mm}$. For larvae in zoeal stage 4 there are peaks in the size distribution at carapace length 1.8, 2.0, 2.2 and $3.0 \mathrm{~mm}$. Pandalid larvae less than 2.0 and $2.7 \mathrm{~mm}$ carapace length in zoeal stages 3 and 4 , respectively, were morphologically identified to Pandalus montagui, and the larger larvae to $P$. borealis after the method described by Ouellet et al. (1990). There was a north-south trend in the stage distributions of the Pandalid larvae (Fig. 6). The majority of the larvae caught on transect 2 were in stages 2 and 3 whereas the majority of the larvae on transects 3 and 4 were in stage 4 . Multi-way ANOVA of larval size (carapace length) showed significant effects of transects, sampling station and type (species and stage) (Table 3 ). However, most of the variation was explained by transect and type. Mean sizes increased significantly from transect 2 to 4 and size varied significantly among species and stages (Table 3 ). One-way ANOVA by species and stage showed no significant $(p>0.05)$ effect of transect for either $P$. borealis or $P$. montagui stage 3 larvae (Table 4). However, the P. montagui stage 4 larvae were significantly $(p<0.001)$ larger on transect 4 compared to transect 2 and 3 . The $P$. borealis stage 4 larvae were significantly $(p<0.05)$ larger on transect 3 compared to transect 4 (Table 4).

\section{Transect 4}

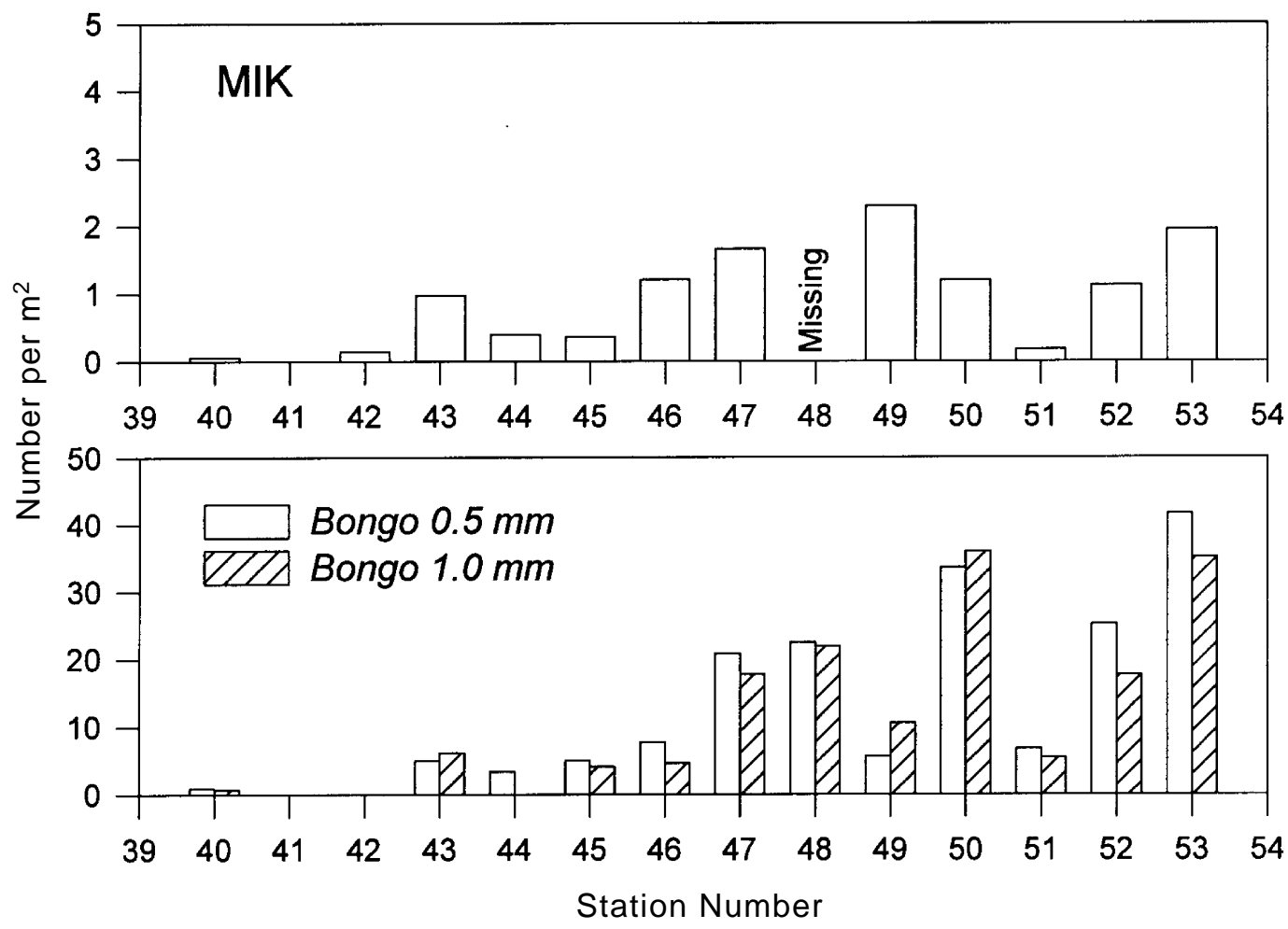

Fig. 5. Comparison of shrimp larvae catches from 3 plankton samplers (MIK, Bongo 0.5 mm, Bongo $1.0 \mathrm{~mm}$ ) along transect 4 . 
TABLE 2. Species and stage composition of shrimp larvae caught in 53 hauls with the MIK plankton sampler.

\begin{tabular}{lccc}
\hline \hline Species & $\begin{array}{c}\text { Number } \\
\text { caught }\end{array}$ & $\begin{array}{c}\% \\
\text { composition }\end{array}$ & Zoeal stage \\
\hline Argis dentata & 1 & $1>0.1$ & 2 \\
Crangonidae sp. & 1 & $>0.1$ & $?$ \\
Eualus galmardi & 18 & 0.2 & 3 \\
Lebbeus groenlandicus & 302 & 3.1 & 2 \\
Pandalus borealis/P. montagui & 8866 & $91.1(32 / 68)$ & $2-5$ \\
Pontophilus (norvegicus?) & 3 & $>0.1$ & $2-3$ \\
Sabinea septemcarinata & 340 & 3.5 & $1-2$ \\
Spirontocaris spinus & 206 & 2.1 & $2-4$ \\
\hline
\end{tabular}

There was a significant $(p<0.001)$ relationship between carapace length and total length for both species, but $\mathrm{r}^{2}$ was relatively low $(0.15-0.41)$ and the linear regression slopes were not significantly different $(p>0.05)$ among species or stages (Fig. 7). However, P. montagui stage 4 showed a broad size range and two apparent relationships a linear and a non-linear between carapace and total length. The wide size range in the Pm-4 larvae is also seen in Figure 6.

There was a significant correlation between the $\log 10$ transformed catches of $P$. montagui and $P$. borealis larvae $(r=0.729, p<0.01, n=33)$. The majority of the larvae were caught in water columns with average temperatures and salinities about $2^{\circ} \mathrm{C}$ and 33 psu, respectively. The catches of $P$. montagui and $P$. borealis larvae showed no correlation with temperature. However, the catches of $P$. montagui larvae were negatively correlated with salinity $(r=$ $-0.447, p<0.01, n=33$ ), whereas $P$. borealis larvae showed no correlation to salinity. There was an increased proportion of $P$. montagui larvae in catches towards the coast on transect 2 and 3 but not on transect 4 (Fig. 8).

\section{Lipid content and condition indices}

Phospholipids (PHO) accounted for the major fraction of the total lipid content in P. montagui and P. borealis larvae (Fig. 9). The triacylglycerols (TAG) were the most abundant neutral lipid followed by wax esters (WAX), free sterols (CHL), and free fatty acids (FFA) (Fig. 9). The FFA/TAG ratio was low $(<0.15)$ in all larvae indicating high quality of the samples and low lipid degradation before, during, and after the storage period (Christie, 1982).
Both TAG to wet weight and TAG to dry weight ratios were investigated as indices of larval feeding condition. The two indices were strongly correlated $(\mathrm{TAG} / \mathrm{DW}-$ index $=10.6 \mathrm{x} \mathrm{TAG} / \mathrm{WW}-$ index, $\left.\mathrm{r}^{2}=0.93, n=160\right)$. The TAG/WW index was used because it was easier to obtain.

Multi-way ANOVA of TAG to wet weight ratios showed significant effects of transect and species (stage), but no significant effect of sampling station within transect (Table 5). One-way ANOVA by transect, species and stage with station as class variable showed no significant $(p>0.05)$ effect of station and no clear trend along each transect in the mean TAG to wet weight ratios (Fig. 10) or in the mean wet weight ratios of other lipid components. Looking at the mean WAX, TAG and FFA to wet weight ratios for each species, stage and transect the mean lipid contents increase from south to north (transect 4 to 2) (Table 6). However, one-way ANOVA revealed that only mean TAG to wet weight ratios for $P$. borealis stage 4 and mean FFA to wet weight ratios (both species and stages) were significantly $(p<0.05)$ different between transects (Fig. 10 and Table 6).

The neutral lipids (WAX + TAG + FFA + CHL) to wet weight ratios were significantly increasing from transect 4 to 2 , from $P$. boralis to P. montagui larvae, and on transect 3 and 4 from costal to offshore stations (Table 7). There was a significant $(p<0.05)$ decrease in the contents of neutral lipids from stage 3 to 4 by species, and by stage $P$. montagui larvae were in significantly better lipid condition than P. borealis larvae (Table 5-7, Fig. 10). As larval size increased the relative TAG content showed a significant decreasing trend for 

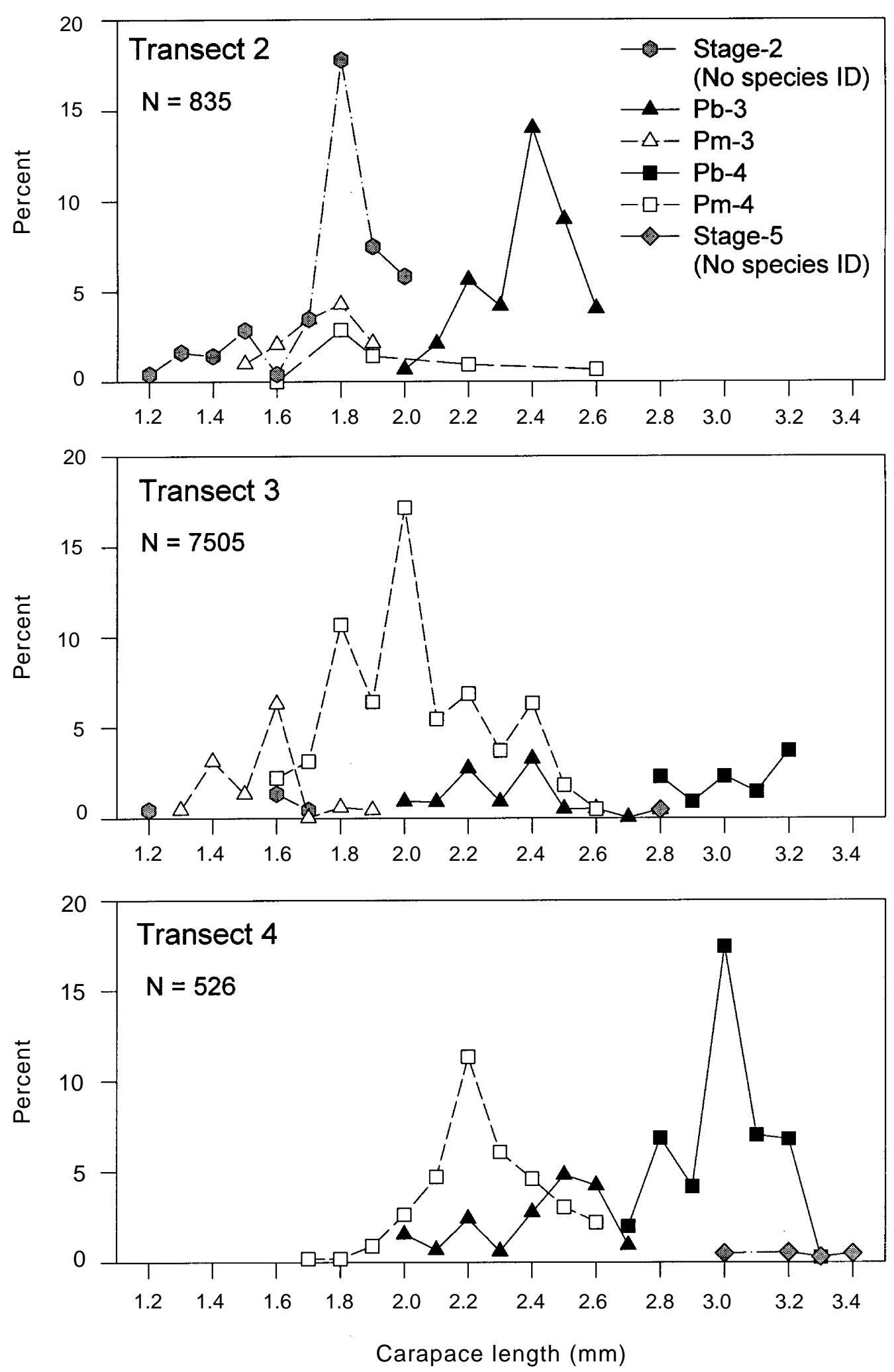

Fig. 6. Size frequency distribution of Pandalus larvae caught with the MIK plankton sampler by transect and larval stage. 
TABLE 3. Results of a nested multi-way ANOVA of larval carapace length (CPL). Model: $\mathrm{CPL}=$ Overall mean $+\mathrm{TR}+\mathrm{TYPE}+\mathrm{ST}(\mathrm{TR})+\mathrm{TYPE}(\mathrm{TR})+$ Err, where TR $=$ transect $2-4$, TYPE $=$ Pandalid species and stage $[P$. borealis $(\mathrm{Pb})$ or $P$. montagui $(\mathrm{Pm})$ and stage 3 or 4$], \mathrm{ST}(\mathrm{TR})=$ sampling station nested within transect, and $\mathrm{TYPE}(\mathrm{TR})=$ species and stage nested within transect.

\begin{tabular}{|c|c|c|c|c|c|}
\hline \multicolumn{6}{|c|}{ Dependent Variable: CPL } \\
\hline Source & d.f. & $\begin{array}{l}\text { Sum of } \\
\text { Squares }\end{array}$ & $\begin{array}{c}\text { Mean } \\
\text { Square }\end{array}$ & F Value & $\operatorname{Pr}>\mathrm{F}$ \\
\hline Model & 33 & 142 & 4.3 & 138 & 0.0001 \\
\hline Error & 798 & 25 & 0.03 & & \\
\hline \multirow[t]{3}{*}{ Corrected Total } & 831 & 168 & & & \\
\hline & R-Square & C.V. & Root MSE & & CPL Mean \\
\hline & 0.85 & 7.6 & 0.2 & & 2.3 \\
\hline & & & Mean & & \\
\hline Source & d.f. & Type I SS & Square & F Value & $\operatorname{Pr}>\mathrm{F}$ \\
\hline TR & 2 & 39.2 & 19.7 & 627.5 & 0.0001 \\
\hline TYPE & 3 & 99.0 & 33.0 & 1054.4 & 0.0001 \\
\hline ST(TR) & 23 & 3.2 & 0.1 & 4.4 & 0.0001 \\
\hline TYPE(TR) & 5 & 1.1 & 0.2 & 7.0 & 0.0001 \\
\hline
\end{tabular}

TABLE 4. Mean carapace length and total length for two stages of P. borealis and P. montagui larvae by sampling transect.

\begin{tabular}{|c|c|c|c|c|c|c|c|c|c|c|c|c|}
\hline \multirow[b]{2}{*}{ Transect } & \multicolumn{3}{|c|}{ P. borealis Stage 3} & \multicolumn{3}{|c|}{ P. borealis Stage 4} & \multicolumn{3}{|c|}{ P. montagui Stage 3} & \multicolumn{3}{|c|}{ P. montagui Stage 4} \\
\hline & No. & Mean & Std. err. & No. & Mean & Std. err. & No. & Mean & Std. err. & No. & Mean & Std. err. \\
\hline \multicolumn{13}{|c|}{ Carapace length (mm) } \\
\hline 2 & 54 & 2.40 & 0.02 & & & & 19 & 1.71 & 0.02 & 9 & 2.01 & 0.10 \\
\hline 3 & 68 & 2.36 & 0.02 & 43 & 3.03 & 0.02 & 85 & 1.66 & 0.02 & 235 & 2.09 & 0.01 \\
\hline 4 & 74 & 2.41 & 0.02 & 136 & 2.97 & 0.01 & 2 & 1.82 & 0.14 & 107 & 2.26 & 0.02 \\
\hline \multicolumn{13}{|c|}{ Total length (mm) } \\
\hline 2 & 6 & 9.94 & 0.35 & & & & 13 & 7.50 & 0.26 & 2 & 8.10 & 1.09 \\
\hline 3 & 46 & 10.23 & 0.09 & 31 & 12.82 & 0.15 & 59 & 7.28 & 0.08 & 173 & 8.96 & 0.06 \\
\hline 4 & 28 & 10.17 & 0.09 & 45 & 12.35 & 0.11 & & & & 70 & 10.13 & 0.16 \\
\hline
\end{tabular}

larvae stage 3 , but no significant relationship for P. borealis or P. montagui in stage 4 (Fig. 11). The relative WAX content showed a similar decreasing trend with larval size for $P$. borealis larvae stage 3 and no relationship with size for $P$. montagui or $P$. borealis stage 4 (Fig. 11). The relative CHL content showed a weak increasing trend with size only for $P$. borealis stage 4 (Fig. 11).

Rank correlation analyses between the TAG condition indices (Pm-4, $\mathrm{Pb}-3$ and $\mathrm{Pb}-4)$ and fluorescence, density of copepod eggs+nauplii, and shrimp larval abundance, respectively, showed sig- nificant correlations only between the TAG condition indices of Pm-4 and fluorescence $(n=7, r=$ $-0.82, p=0.03)$ and density of copepod eggs + nauplii $(n=4, r=-1.0, p=0.0001)$.

\section{Discussion}

\section{Abundance and distribution}

The proportionate representation of $P$. montagui $(68 \%)$ and $P$. borealis $(32 \%)$ larvae in our samples does not correspond to current estimates of adult stock size of the two Pandalid species at West 

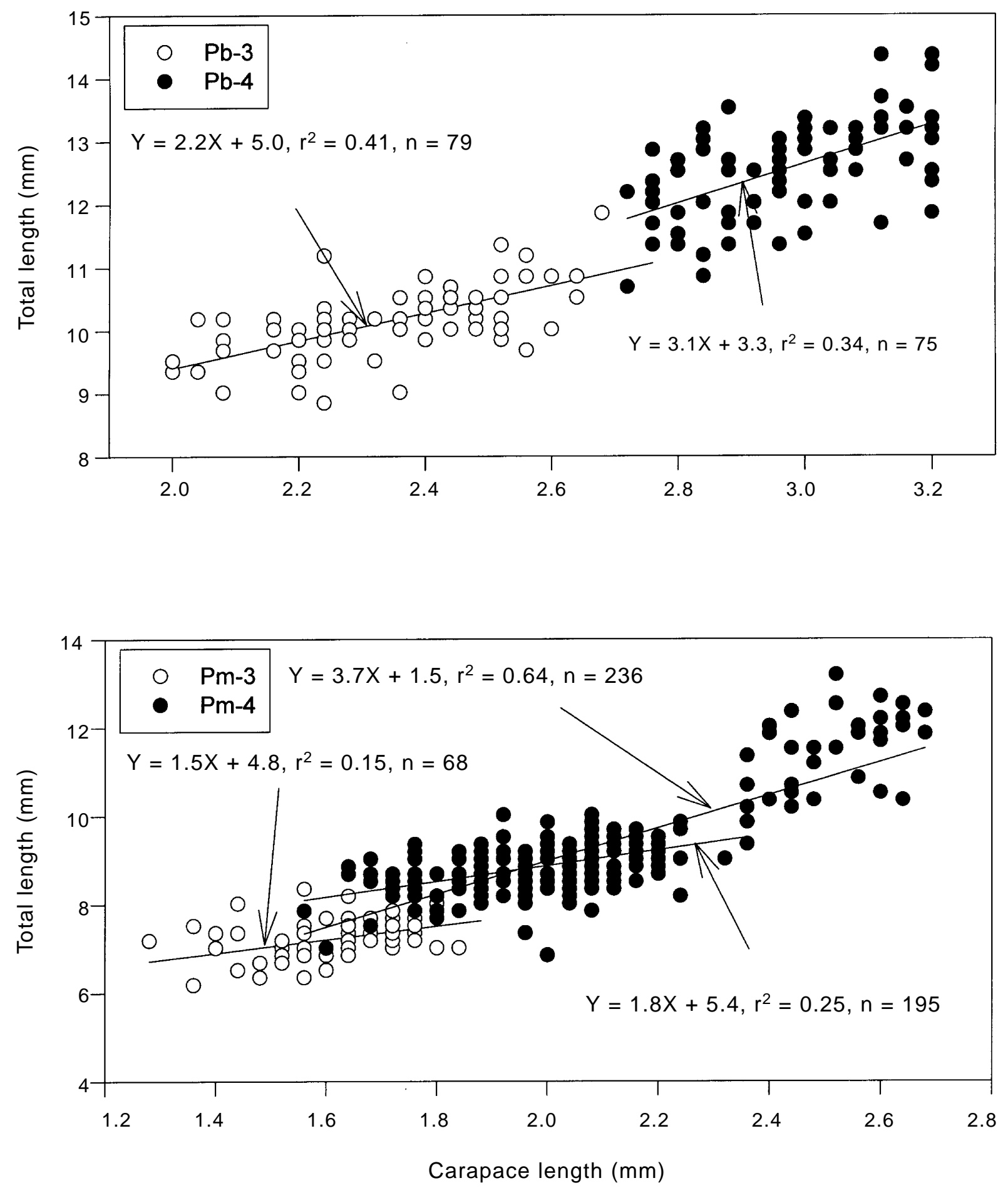

Fig. 7. Carapace length versus total length of P. borealis (top) and P. montagui (bottom) stage 3 and 4 larvae.

Greenland. The stock size of $P$. borealis is far larger as reflected in catch statistics and fishery-independent surveys. However, the Greenlandic fishery for $P$. borealis has observed an increasing amount of
P. montagui in catches from some fishing grounds in recent years. Biomass indices from the annual Greenlandic shrimp assessment survey off West Greenland indicate a rapid increase in population 
Transect 2

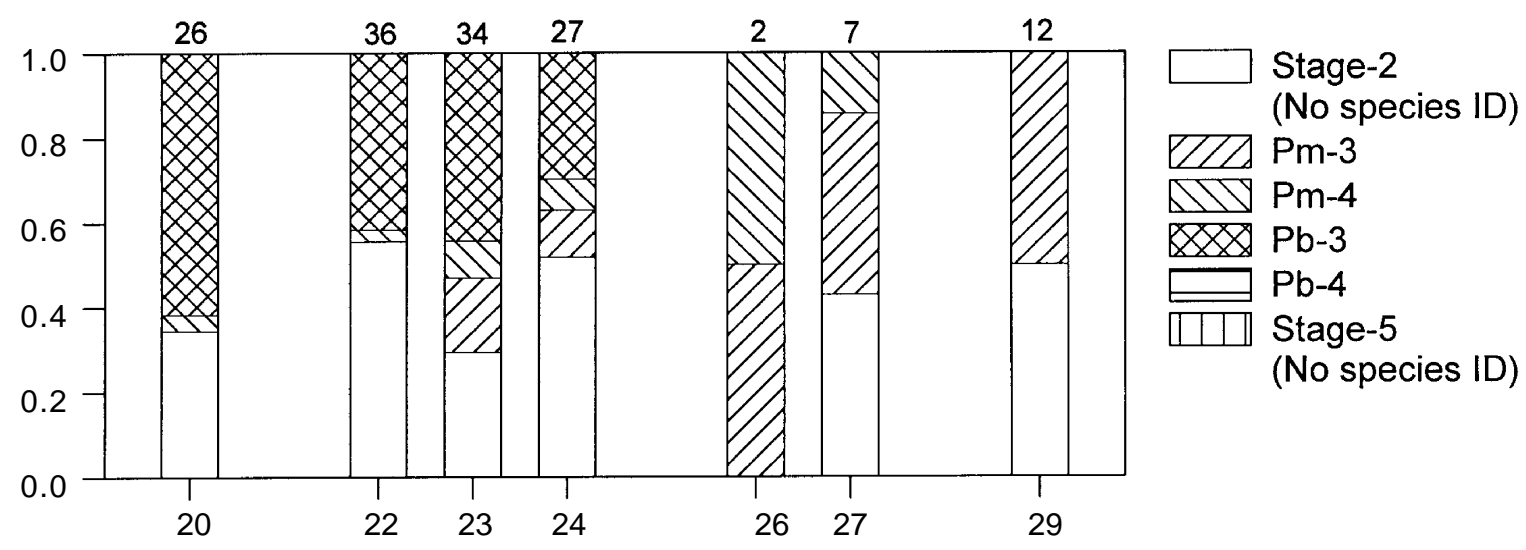

Transect 3

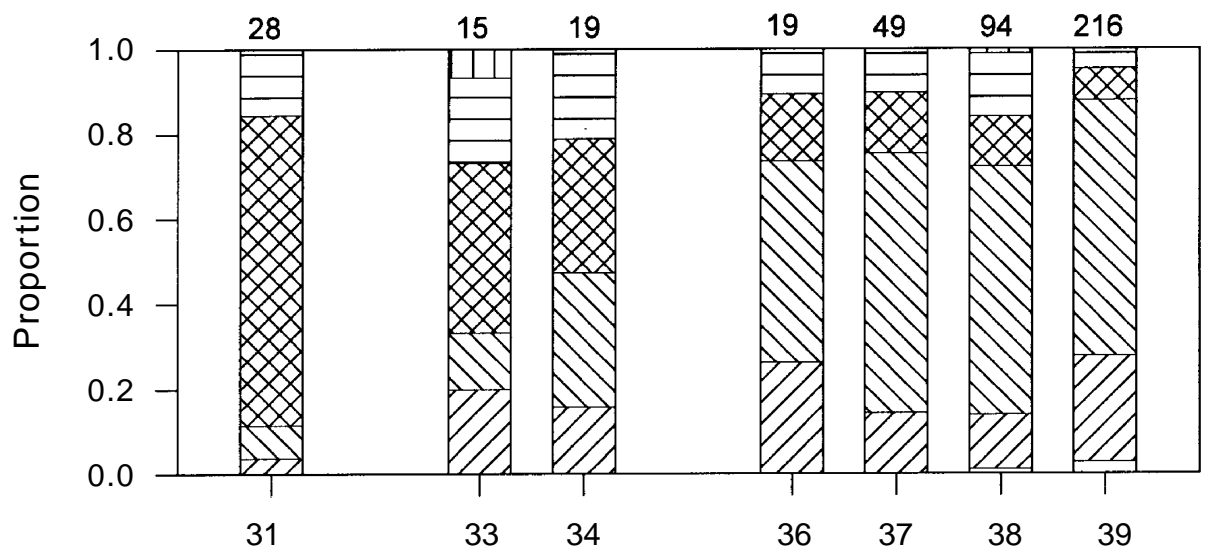

Transect 4

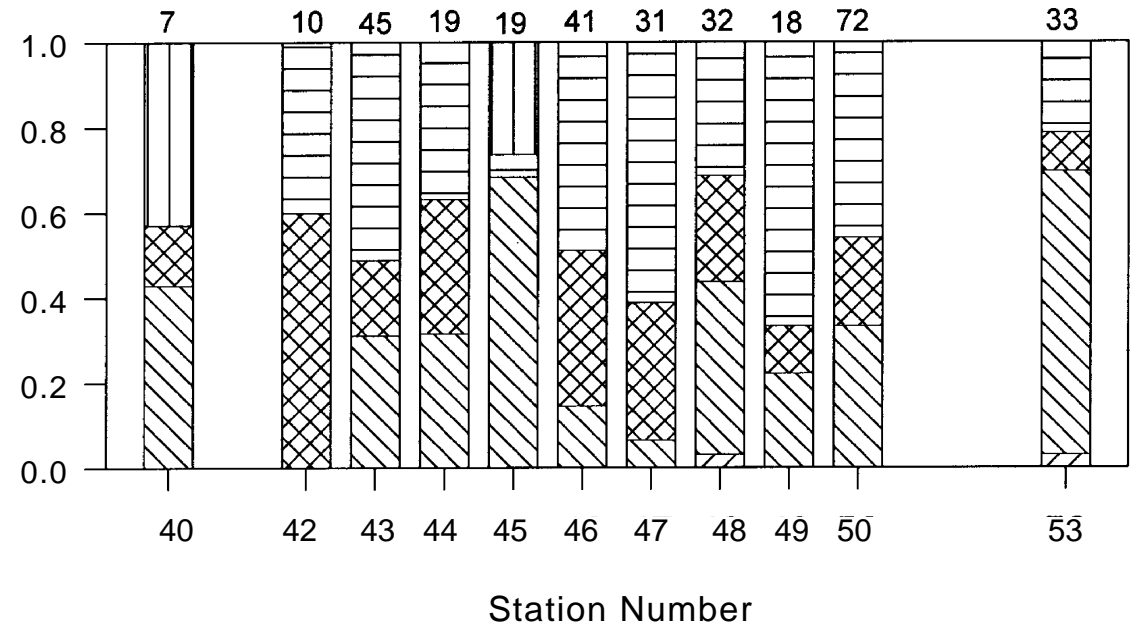

Fig. 8. Proportion of Pandalus larvae (species and stages) in the catches by transect and station. Number of larvae identified is given on the top of the columns. 


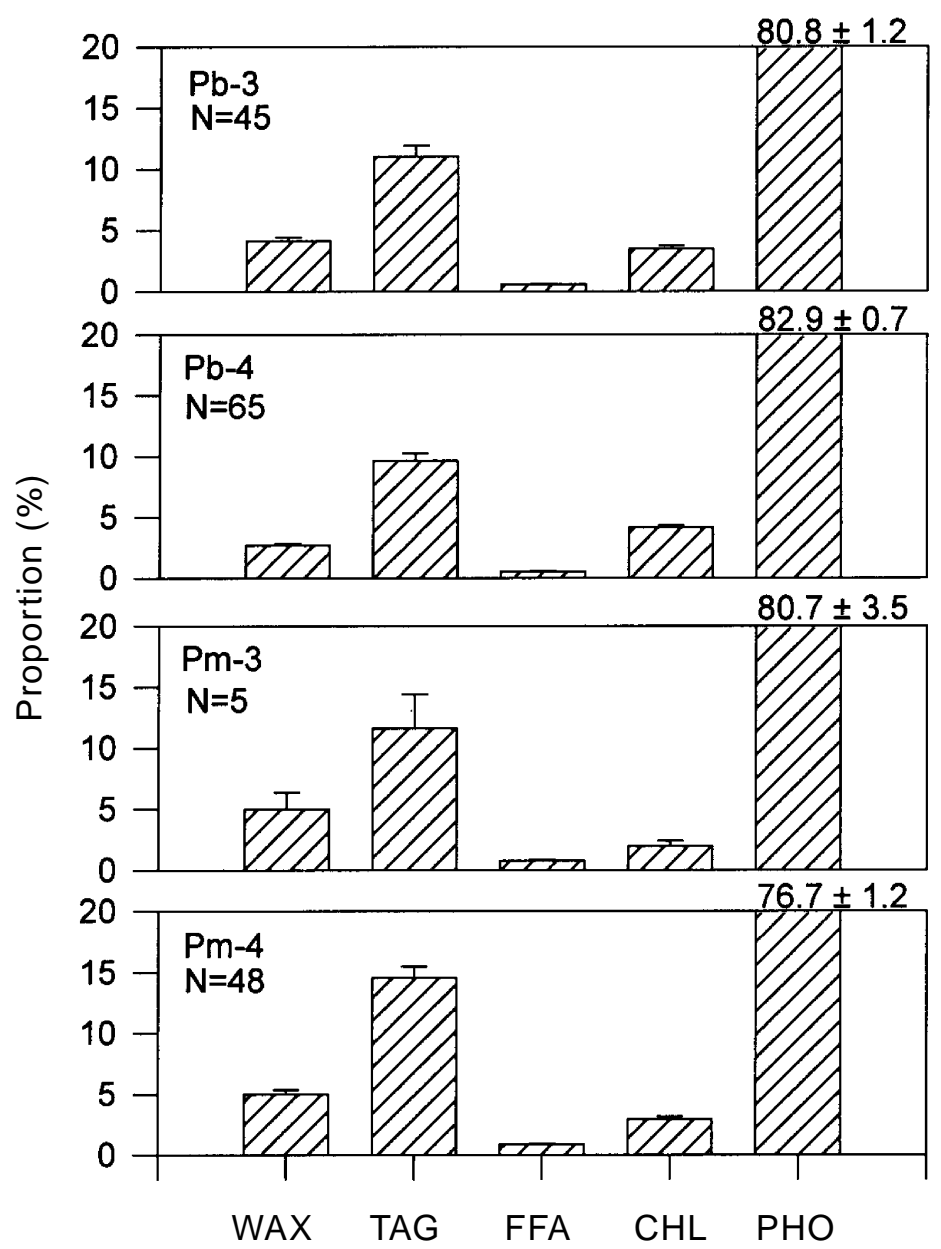

Fig. 9. Percent lipid composition of $P$. borealis and P. montagui larvae. $95 \%$ confidence interval indicated on columns.

TABLE 5. Results of a nested multi-way ANOVA of TAG to wet weight ratios (TAGI). Model: TAGI $=$ Overall mean + TR + TYPE + ST $(\mathrm{TR})+$ Err, where TR $=$ transect $2-4$, TYPE $=$ Pandalid species and stage $[$ P. borealis $(\mathrm{Pb})$ or $P$. montagui $(\mathrm{Pm})$ and stage 3 or 4], ST(TR) = sampling station nested within transect.

\begin{tabular}{|c|c|c|c|c|c|}
\hline \multicolumn{6}{|c|}{ Dependent Variable: TAGI } \\
\hline Source & d.f. & $\begin{array}{l}\text { Sum of } \\
\text { Squares }\end{array}$ & $\begin{array}{l}\text { Mean } \\
\text { Square }\end{array}$ & F Value & $\operatorname{Pr}>F$ \\
\hline Model & 14 & 1349 & 96.4 & 5.9 & 0.0001 \\
\hline Error & 148 & 2437 & 16.5 & & \\
\hline \multirow[t]{3}{*}{ Corrected Total } & 162 & 3786 & & & \\
\hline & R-Square & C.V. & Root MSE & & TAGI Mean \\
\hline & 0.36 & 41.0 & 4.1 & & 9.9 \\
\hline Source & d.f. & Type I SS & Mean Square & F Value & $\operatorname{Pr}>F$ \\
\hline TR & 2 & 652.7 & 326.3 & 19.8 & 0.0001 \\
\hline TYPE & 3 & 423.7 & 141.2 & 8.6 & 0.0001 \\
\hline ST(TR) & 9 & 273.1 & 30.4 & 1.8 & 0.0650 \\
\hline
\end{tabular}




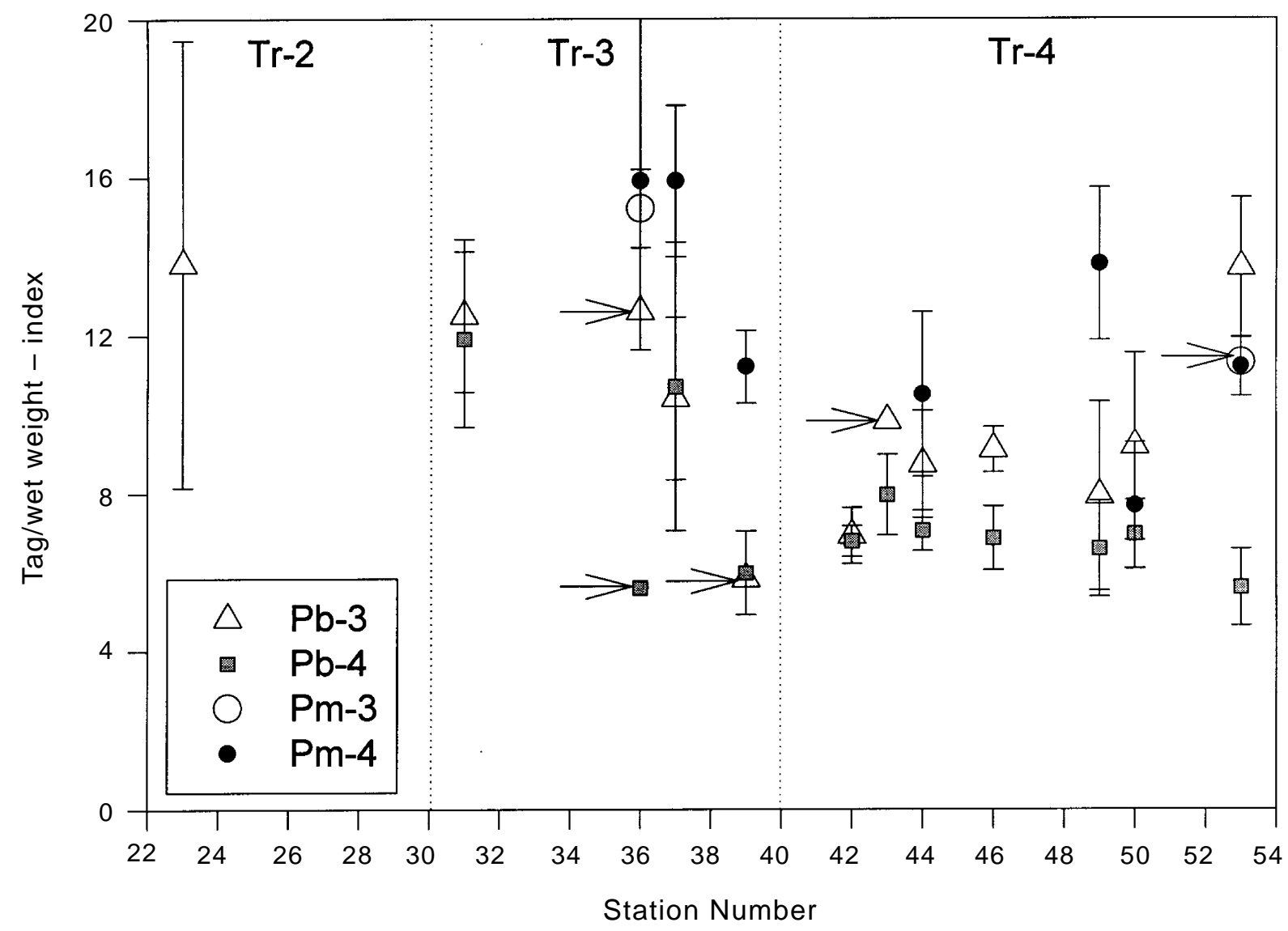

Fig. 10. Mean TAG/wet weight condition index with $95 \%$ confidence interval by species, stage, and sampling station. (Arrows indicate points of only one observation).

size of P. montagui between 1988 and 1996 (Folmer, MS 1996). No previous records of $P$. montagui larvae exist from West Greenland waters (Stephensen, 1935; Horsted and Smidt, 1956; Horsted et al., MS 1978; Smidt, 1979). The high proportion of $P$. montagui larvae found in this study suggests that the stock of $P$. montagui may continue to increase in the coming years.

Changes in climate can have a considerable impact on the productivity of fisheries resources (Glantz and Feingold, 1992). Research in climatic variability indicates that a future global temperature increase might result in a colder climate and a changed sea environment at Greenland (and in other local areas of the north Atlantic) due to increased melt off from the Greenlandic icecap (Broecker, 1991). In recent years an increasing amount of the annual shrimp catches off West Greenland has been taken in the southern part of the northern shrimp distribution area, and there has been an increase in the catches of less valuable shrimp species, mainly P. montagui (Anon., 1997; Folmer, MS 1996). Both of these trends may be indications for a changed and colder sea environment. The latter is supported by a general cooling trend from the late-1960s onwards in the sea temperature time-series from off West Greenland (Stein and Borovkov, 1997).

\section{Larval distribution}

P. borealis in West Greenland spawn in offshore waters starting in July and ending in late-August or early-September (Horsted, 1978). The egg mass is carried by females until spring (March-April) when females move to shallow water to release the first pelagic larval stage (Horsted, 1978; Shumway et al., 1985). The planktonic larvae are thought to drift more or less passively during five zoeal stages (approximately 4 months) and settle to the bottom during the sixth (megalopa) stage (Berkeley, 1930; Horsted et al., MS 1978; Shumway et al., 1985). 
TABLE 6. Mean wet weight (frozen specimens) and lipid (WAX, TAG, FFA, CHL, and PHO) to wet weight indices for two stages of $P$. borealis and $P$. montagui by sampling transect.

\begin{tabular}{|c|c|c|c|c|c|c|c|c|c|c|c|c|}
\hline \multirow[b]{2}{*}{ Transect } & \multicolumn{3}{|c|}{ P. borealis Stage 3} & \multicolumn{3}{|c|}{ P. borealis Stage 4} & \multicolumn{3}{|c|}{ P. montagui Stage 3} & \multicolumn{3}{|c|}{ P. montagui Stage 4} \\
\hline & No. & Mean & Std. err. & No. & Mean & Std. err. & No. & Mean & Std. err. & No. & Mean & Std. err. \\
\hline \multicolumn{13}{|c|}{ Wet Weight (mg) } \\
\hline 2 & 2 & 6.61 & 0.28 & & & & & & & & & \\
\hline 3 & 16 & 7.63 & 0.39 & 11 & 12.09 & 0.47 & 4 & 3.85 & 0.54 & 32 & 6.13 & 0.19 \\
\hline 4 & 27 & 7.36 & 0.29 & 54 & 11.83 & 0.28 & 1 & 3.65 & & 18 & 5.90 & 0.35 \\
\hline \multicolumn{13}{|c|}{ WAX/Wet Weight - Index } \\
\hline 2 & 2 & 6.37 & 0.62 & & & & & & & & & \\
\hline 3 & 16 & 4.23 & 0.37 & 11 & 2.79 & 0.33 & 4 & 10.00 & 4.84 & 30 & 4.58 & 0.43 \\
\hline 4 & 27 & 3.53 & 0.36 & 54 & 2.13 & 0.16 & 1 & 3.36 & & 18 & 4.08 & 0.46 \\
\hline \multicolumn{13}{|c|}{ TAG/Wet Weight - Index } \\
\hline 2 & 2 & 13.79 & 5.66 & & & & & & & & & \\
\hline 3 & 16 & 11.73 & 1.42 & 11 & 9.40 & 1.43 & 4 & 15.22 & 0.99 & 30 & 13.43 & 1.07 \\
\hline 4 & 27 & 8.84 & 0.67 & 54 & 7.03 & 0.39 & 1 & 11.28 & & 18 & 11.23 & 0.78 \\
\hline \multicolumn{13}{|c|}{ FFA/Wet Weight - Index } \\
\hline 2 & 2 & 0.94 & 0.02 & & & & & & & & & \\
\hline 3 & 16 & 0.69 & 0.05 & 11 & 0.66 & 0.07 & 4 & 1.55 & 0.23 & 30 & 0.99 & 0.04 \\
\hline 4 & 27 & 0.42 & 0.04 & 54 & 0.38 & 0.02 & 1 & 0.23 & & 18 & 0.46 & 0.04 \\
\hline \multicolumn{13}{|c|}{ CHL/Wet Weight - Index } \\
\hline 2 & 2 & 2.93 & 0.38 & & & & & & & & & \\
\hline 3 & 16 & 2.89 & 0.11 & 11 & 2.96 & 0.15 & 4 & 2.75 & 0.14 & 30 & 2.41 & 0.07 \\
\hline 4 & 27 & 3.44 & 0.41 & 54 & 3.26 & 0.14 & 1 & 1.85 & & 18 & 2.73 & 0.58 \\
\hline \multicolumn{13}{|c|}{ Neutral lipid (WAX + TAG + FFA + CHL)/Wet Weight - Index } \\
\hline 2 & 2 & 24.04 & 6.64 & & & & & & & & & \\
\hline 3 & 16 & 19.53 & 1.63 & 11 & 15.81 & 1.41 & 4 & 29.51 & 4.70 & 30 & 21.41 & 1.10 \\
\hline 4 & 27 & 16.23 & 0.94 & 54 & 12.80 & 0.48 & 1 & 16.71 & & 18 & 18.51 & 0.94 \\
\hline \multicolumn{13}{|c|}{ PHO/Wet Weight - Index } \\
\hline 2 & 2 & 71.13 & 11.42 & & & & & & & & & \\
\hline 3 & 16 & 88.37 & 6.65 & 11 & 82.41 & 6.42 & 4 & 164.08 & 43.01 & 30 & 90.63 & 7.57 \\
\hline 4 & 27 & 88.11 & 13.06 & 54 & 65.94 & 3.34 & 1 & 38.33 & & 18 & 53.51 & 4.95 \\
\hline
\end{tabular}

On transects 2 and $3 P$. montagui larvae dominated at the stations closest to the coast, whereas $P$. borealis dominated offshore. The abundance of $P$. montagui larvae was negatively related to salinity whereas $P$. borealis showed no relation to salinity. Horsted et al. (MS 1978) indicated that $P$. borealis larvae were more abundant at depths below $50 \mathrm{~m}$. This difference in larval distribution may be related to differences in the distribution of adults. In the annual Greenlandic shrimp assessment survey off West Greenland covering depths from 50 to $600 \mathrm{~m}$, P. montagui have been caught mainly at depths between 200 and $300 \mathrm{~m}$ and $P$. borealis mainly at depths between 300 and $400 \mathrm{~m}$ (Folmer, MS 1996; Folmer et al., MS 1996). In Penobscot
Bay (USA), P. montagui adults were most common at depths between 20 and $90 \mathrm{~m}$, whereas $P$. borealis most often dominated in deeper water (Stevenson and Pierce, 1985). P. montagui is the only Pandalid species which inhabits Arctic waters $<1.5^{\circ} \mathrm{C}$ and it is prevalent in the cold $\left(-1\right.$ to $\left.2^{\circ} \mathrm{C}\right)$, well-mixed water of Arctic origin which becomes the "cold intermediate layer" in the Northwest Atlantic (Squires, 1966; Hudon et al., 1992). P. borealis is characteristically found in the deep (150-500 m), warm $\left(2-5^{\circ} \mathrm{C}\right)$, stratified layer of Atlantic origin located below the intermediate cold layer (Hudon et al., 1992). P. montagui differs from P. borealis by being more depth, temperature, and salinity tolerant (Hudon et al., 1992). 
TABLE 7. Results of a nested multi-way ANOVA of neutral lipids to wet weight ratios (NLIPI). Model: NLIPI = Overall mean + TR + TYPE + ST(TR) + Err, where $\mathrm{TR}=$ transect $2-4$, TYPE $=$ Pandalid species and stage $[P$. borealis $(\mathrm{Pb})$ or P. montagui $(\mathrm{Pm})$ and stage 3 or 4$], \mathrm{ST}(\mathrm{TR})=$ sampling station nested within transect.

\begin{tabular}{lccccc}
\hline \hline Dependent Variable: & NLIPI & & & \\
Source & d.f. & $\begin{array}{c}\text { Sum of } \\
\text { Squares }\end{array}$ & $\begin{array}{c}\text { Mean } \\
\text { Square }\end{array}$ & F Value & Pr > F \\
Model & 14 & 2840 & 202.8 & 8.76 & 0.0001 \\
Error & 148 & 3426 & 23.2 & & \\
Corrected Total & 162 & 6266 & & & \\
& & & & & \\
& R-Square & C.V. & Root MSE & & NLIPI Mean \\
& 0.45 & 28.3 & 4.8 & & 17.0 \\
Source & d.f. & Type I SS & Mean Square & F Value & Pr > F \\
TR & 2 & 1308.5 & 654.3 & 28.3 & 0.0001 \\
TYPE & 3 & 1054.4 & 351.5 & 15.2 & 0.0001 \\
ST(TR) & 9 & 476.8 & 53.0 & 2.3 & 0.0197 \\
\hline
\end{tabular}

The general features of the current system and water mass distribution around Greenland have been described by Buch (MS 1994). In the present study there was a trend of older Pandalus larvae from north to south. The water temperatures show an analogous increasing trend from north to south. However, larval abundance was not related to temperature for either of the species.

Larvae from transects 2, 3, and 4 are probably not from the same spawning/hatching population. Most of the larvae in stage 2 were identified as $P$. borealis and a higher proportion in stage 4 were $P$. montagui, suggesting that $P$. borealis larvae were hatched later. Eggs and larvae of the West Greenland shrimp populations appear to show a delay in hatching and development from south to north, related to the later warming and onset of primary and secondary production from south to north. A timeseries of zooplankton collections off West Greenland (1956-1984) shows that shrimp larvae occur earlier (May-June) in south-west Greenland, than further north in the Disko Bay area (July-August) (Pedersen and Smidt, MS 1995; Pedersen, unpubl. data). Temperature has a strong effect on larval growth and development time of Pandalid larvae (Shumway et al., 1985; Rasmussen, MS 1993; Tande et al., 1994; Rasmussen and Tande, 1995).

P. borealis larvae hatched at south-west Greenland may be transported several hundred naut. miles by the net northward West Greenland current dur- ing their planktonic larval life (Horsted et al., MS 1978). The current speed along West Greenland decreases from south to north and also with depth in the northern area. Considering the possibility that current gyres occur in the shrimp area north-west of Store Hellefiske Bank (Fig. 12) it seems likely that the stock in this area is recruited not only from more southerly populations, but possibly to a much greater extent by its own larval source (Horsted et $a l$, MS 1978). These hypothesized larval drift routes assume that larvae can be considered as passive particles in the water mass. In the present study, a weak trend was found of younger larvae from south (majority of stage 4) to north (majority of stage 2 and 3 ) which does not support the hypothesis of an entirely passive northward drift of larvae hatched in the south.

\section{Lipid composition and larval condition}

The structural lipid fraction (i.e. phospholipids) accounted for most of the total lipid in both $P$. borealis, and $P$. montagui larvae. Ouellet et al. (1995) similarly found phospholipids to be the most abundant lipid class in $P$. borealis larvae (zoeal stage 1 and 2) from Gulf of St. Lawrence. However, triacylglycerols (TAG) accounted for the major fraction of the total lipid in P. borealis from Balsfjord (Hopkins et al., 1993). TAG is the primary storage form (as fat) of organic energy in $P$. borealis, and therefore the TAG to wet weight ratio $(($ TAG $\mathrm{mg} / \mathrm{WW} \mathrm{mg}) \times 1000))$ can be used as 


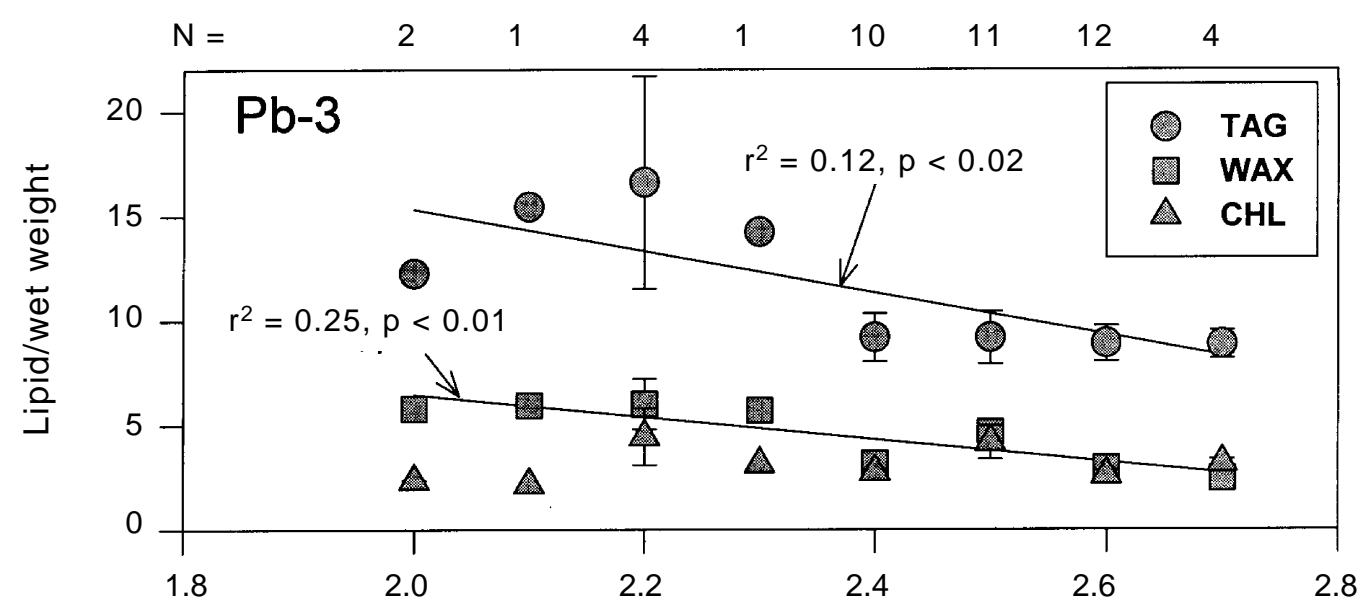

Carapace length $(\mathrm{mm})$
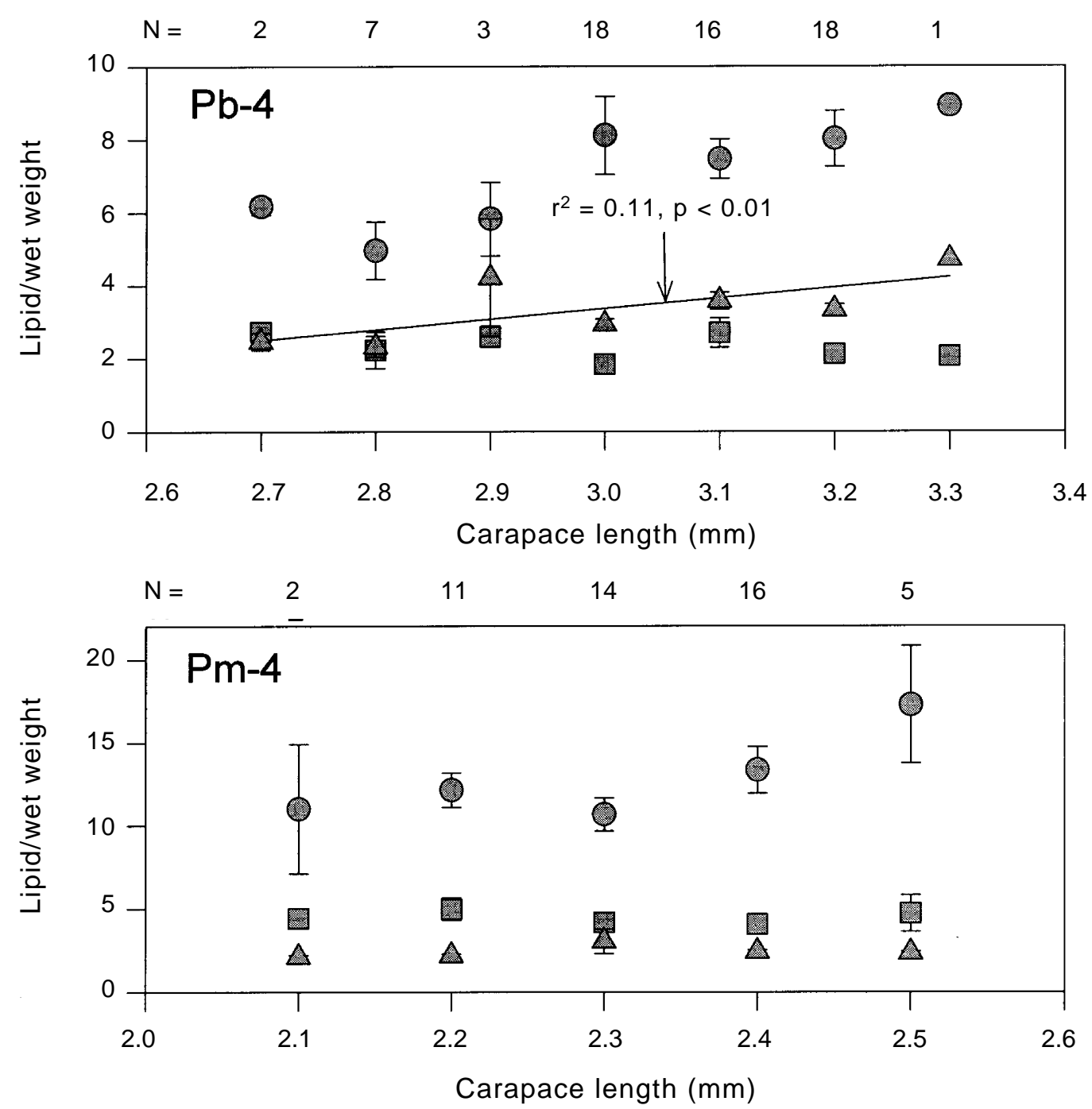

Fig. 11. Mean TAG, WAX and CHL condition indices by size, species, and stage. 95\% confidence interval shown. Sample number given on the top of each figure. Fitted lines are shown for significant relationships. 
an index for larval feeding condition (Ouellet et al., 1992; Hopkins et al., 1993). Ouellet et al. (1995) found a high content of the diacylglycerols (DAG) in shrimp larvae, which could reflect lipid degradation during storage or metabolic activity. In the present study the second largest lipid fraction was TAG, whereas no DAG was found.

The larvae used for lipid content analyses in this study were randomly picked from catches at selected stations and represent different sizes of $P$. borealis larvae in stages 3 and 4 , and $P$. montagui larvae in stage 4. With larval size WAX and TAG contents showed decreasing trends for $P$. borealis larvae stage 3 , and no trend for $P$. borealis and $P$. montagui stage 4 . This could indicate that the larvae use more lipid than they accumulate in the period before molting from stage 3 to 4 . The CHL content showed a weak increasing trend with size only for P. borealis stage 4. CHL is used in building cells and is not as accessible for energy use as WAX and TAG.

Ouellet et al. (1992, 1995) found a relationship between the proportion of $P$. borealis larvae (zoeal stages 1 and 2) with a TAG condition index below 0.2 and the probability of survival during the next moult. In the present study the larvae were further developed (zoeal stages 3 and 4) and none of them showed a TAG condition index below 0.2. However, the TAG condition indices of the $P$. montagui larvae were generally higher than for the $P$. borealis larvae, suggesting they may have a higher growth and survival potential during their first winter (a catabolic period with drain in the energy budget) (Hopkins et al., 1993). The P. montagui larvae seem to be in a better feeding condition based on a generally higher content of neutral lipids.

In the Gulf of St. Lawrence, P. borealis larvae (zoeal stages 1 and 2) maintained their vertical position in the subsurface chlorophyll $a$ and suspended particle concentration maxima during the day but moved towards the surface at night (Ouellet and Lefaivre, 1994). Zoeal stage 2 larvae were larger in weight and length, and showed a higher TAG condition index at sites where developmental stages of calanoid copepods were more abundant (Ouellet et al., 1995). Ouellet et al. (1995) conclude that secondary production in the water column influences growth, condition, and survival potential of shrimp larvae. They propose that larval survival and recruitment to the fishable stocks are influenced by factors affecting stratification and mixing in the water column (i.e. buoyancy fluxes), and hence phytoplankton and copepod production in the northern Gulf of St. Lawrence. In this study it was not possible to demonstrate similar relationships between TAG condition indices and primary and secondary production. A significant negative association was found between TAG condition indices and both fluorescence and copepod productivity for $P$. montagui stage 4 larvae and no association for $P$. borealis stage 3 and 4 larvae. Hence, the TAG content may not be linked to productivity for stage 3 and 4 larvae. However, the spatial and temporal resolution of the samples in the present study may have been too low to capture a link if it exists. Of immediate interest is whether $P$. borealis larvae are more abundant at depths below $50 \mathrm{~m}$ as indicated by Horsted et al. (MS 1978).

\section{MIK and Bongo sampling}

Our sampling was hindered by large amounts of algae "slime" (algae threads and colonies)

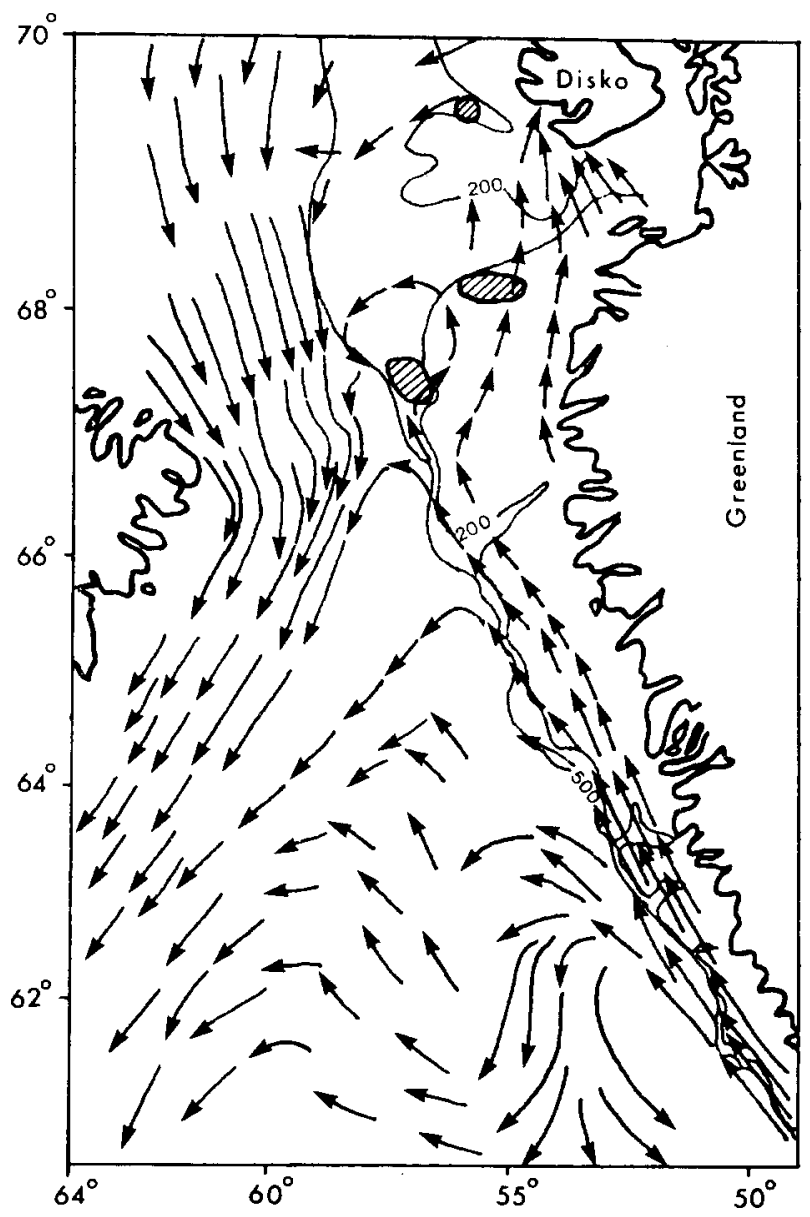

Fig. 12. The areas of near bottom shrimp larvae (stages 4-6) occurrence in August-September off West Greenland (shaded areas) and a scheme of the Davis Strait currents (from Klimenkov et al. 1978). 
especially in the coastal areas of transects 3 and 4 . This was particularly a problem in the MIK sampler, which was very difficult to clean properly between the hauls due to size and net material. The smaller and lighter Bongo nets were easier to handle, wash, and clean. The generally lower shrimp larvae density estimated from the MIK sampler were probably due to greater net clogging and reduced filtration. On transects 1 and 2 there was little algae "slime" in the water and, therefore, little reduction in the MIK sampler filtration.

\section{Species identification}

The larvae of P. montagui are somewhat smaller but morphologically very similar to $P$. borealis, and the time of hatching and duration of the planktonic phase is also similar (Ouellet et al., 1990; Astthorsson and Gislason, 1991). In this study larvae identified to $P$. montagui had yellow pigmentation at the base of the pleopods; this pigmentation was lacking on larvae identified to $P$. borealis. $P$. borealis larvae had red pigmentation on the edge of carapace on most specimens. These pigment patterns were most clearly seen on frozen specimens, but also visible on some formalin preserved specimens. There was correspondance between species identifications based on numbers of setae on the antenna scale (Ouellet et al., 1990) and their pigment patterns. In this study, pleopods 2 to 5 on $P$. montagui larvae zoeal stage 3 were biramous and most were more advanced than the stage 3 larvae described by Pike and Williamson (1964), and Squires (1993).

The great size range of $P$. montagui larvae stage 4 found in this study may be explained by misjudgement of large specimens which actually were $P$. montagui larvae in stage 5 or $P$. borealis in stage 3 (or 4). Another less likely explanation is that some large $P$. montagui larvae belong to a different species and were misidentified. However, genetic discrimination and verification of the identified P. montagui larvae in this study are desirable. The characteristics and sizes of the $P$. borealis larvae from West Greenland in this study agreed well with descriptions of Haynes (1979) and findings from Ísafjord-deep, north-west Iceland (Astthorsson and Gislason, 1991).

\section{Conclusions}

This study was a first attempt to investigate shrimp larvae distribution and lipid composition in relation to hydrography in West Greenland waters.
Though I did not find clear relationships, my results suggest that future studies should investigate lipid condition of the earliest stages of $P$. borealis and $P$. montagui larvae and establish trophic relationships (lipid nutrition) using food web tracer lipids (St. John and Lund, 1996). Hence, sampling should take place earlier (end of May) and further to the south compared to transect positions in the present study. Vertical sampling and drift studies of larval patches are needed to study larval distribution, growth and survival in relation to variable hydrographical and biological characteristics of the larval environment. Such studies could be important to achieve better recruitment predictions for both species.

\section{Acknowledgement}

Thanks to Greenland Institute of Natural Resources, the crew on R/V Adolf Jensen, Peter Munk, Marc Andersen, Lasse Riemann for excellent cooperation during the cruise. Thanks also to Mads Thomsen, and to the Danish Fisheries Research Institute, Department of Marine and Coastal Ecology (especially Mike St. John, Marlene Carlsen, Peter Munk and Sigrun Jónasdóttir) for discussions and help in the laboratory. Thanks to Patrick Ouellet, Don Parsons, and one anonymous reviewer for comments to an early draft of this paper. Special thanks to R. Anne Richards for guidelines, critical reviews, and substantial rewording to improve the manuscript. This work was based on economic support from the Danish Research Councils Committee on Polar Research, Project no. 9501038 - Benni Hansen, Roskilde University Center.

\section{References}

ANON. 1985. SAS User's Guide: Basics/Statistics Version 5. SAS Institute Inc., Raleigh, North Carolina. 1997. NAFO Scientific Council Reports 1996. NAFO Sci. Coun. Rep., 1996: 226 p.

ASTTHORSSON, O. S., and A. GISLASON. 1991. Seasonal abundance and distribution of Caridea larvae in Ísafjord-deep, north-west Iceland. Plank. Res. 13(1): 91-102.

BERKELEY, A. A. 1930. The post-embryonic development of the common Pandalids of British Columbia. Contrib. Can. Biol., 6: 79-163.

BROECKER, W. S. 1991. The great ocean conveyor. Oceanography, 4(2): 79-89.

BUCH, E. MS 1994. A monograph on the physical environment of Greenland waters. Royal Danish Administration of Navigation and hydrography, Copenhagen, Denmark, 405 p.

CARLSSON, D. M. 1997. Review of shrimp research in 
the North Atlantic - Greenland waters. In: Northern shrimp research in the North Atlantic - state of the art and future research strategy. C. Hvingel (ed.). Nordic Council of Ministers. TemaNoed, 592: 40-44.

CAMPBELL, R. C. 1975. Statistics for biologists. Cambridge University Press. 385 p.

CHRISTENSEN, S., and N. VESTERGAARD. 1993. A Bioeconomic Analysis of the Greenland Shrimp Fishery in the Davis Strait. Mar. Res. Econ., 8: 345365.

CHRISTIE, W. W. 1982. Lipid analysis: isolation, separation, identification, and structural analysis of lipids. 2nd ed. Pergamon Press, Oxford. 197 p.

CLARKE, A. 1979. Lipid content and composition of the pink shrimp, Pandalus montagui (Leach) (Crustacea: Decapoda). J. Exp. Mar. Biol. Ecol., 38: 1-17.

CUSHING, D. 1995. Population production and regulation in the sea: A Fisheries perspective. Cambridge University Press. 354 p.

FOLMER, O. MS 1996. Occurrence of Striped Shrimp (Pandalus montagui) along the west coast of Greenland from 1988 to 1996. NAFO SCR Doc., No. 113, Serial No. N2810, 4 p.

FOLMER, O., D. M. CARLSSON,C. HVINGEL, and P. KANNEWORFF, P. MS 1996. Offshore trawl survey for shrimp (Pandalus borealis) in NAFO Subareas 0 and 1, in 1996. NAFO SCR. Doc., No. 114, Serial No. N2811, 20 p.

GLANTZ, M. H., and L. E. FEINGOLD. 1992. Climate variability, climate change, and fisheries: a summary. In: Climate variability, climate change, and fisheries. M. H. Glantz (ed.). Cambridge University Press, Chapter 17: 417-438.

HAYNES, E. 1978. Description of larvae of a hippolytid shrimp, Lebbeus groenlandicus, reared in situ in Kachemak Bay, Alaska. Fish. Bull. U.S., 76: 457465.

1979. Description of larvae of the Northern Shrimp, Pandalus borealis, reared in situ in Kachemak Bay, Alaska. Fish. Bull. U.S., 76: 457465.

1985. Morphological development, identification, and biology of larvae of Pandalidae, Hippolytidae, and Crangonidae (Crustacea, Decapoda) of the northern North Pacific Ocean. Fish. Bull. U.S., 83: 253-288.

HOPKINS, C. C. E., J. R. SARGENT, and E. M. NILSSEN. 1993. Total lipid content, and lipid and fatty acid composition of the deepwater prawn Pandalus borealis from Balsfjord, northern Norway: growth and feeding relationships. Mar. Ecol. Prog. Ser., 96: 217-228.

HORSTED, S. A. 1978. Life cycle of the shrimp, Pandalus borealis Krøyer, in Greenland waters in relation to the potential yield. ICNAF Sel. Pap., 4: 51-60.

HORSTED, S.A., and E. SMIDT. 1956. The deep sea prawn (Pandalus borealis, Kr.) in Greenland waters. Medd. Dan. Fisk. Havunders $\phi .$, N.S., 1(11), 118 p.
HORSTED, S. A., JOHANSEN, P., and E. SMIDT. MS 1978. On the possible drift of shrimp larvae in the Davis Strait. ICNAF Res. Doc., No. 93, Serial No. 5309, 13 p.

HUDON, C., D. G. PARSONS, and R. CRAWFORD. 1992. Diel pelagic foraging by a Pandalid shrimp (Pandalus R. montagui) off Resolution Island (Eastern Hudson Strait). Can. J. Fish. Aquat. Sci., 49: 565-576.

HVINGEL, C. 1997. Northern shrimp research in the North Atlantic - state of the art and future research strategy. Nordic Council of Ministers. TemaNoed. 592: $64 \mathrm{p}$.

KLIMENKOV, A. I., B. I. BERENBOIM, and A. YU. LYSY. 1978. USSR investigations on shrimp in the West Greenland Area, 1976. ICNAF Sel. Pap., 4: 47-50.

MUNK, P. MS 1993. Describing the distribution and abundance of small 0-group cod using ring-net sampling and echo-integration. ICES C.M. Doc., No. $\mathrm{G}: 40,13 \mathrm{p}$.

MUNK, P., P. O. LARSSON, D. DANIELSEN, and E. MOKSNESS. 1995. Larval and small juvenile cod (Gadus morhua) concentrated in the highly productive areas of a shelf break front. Mar. Ecol. Prog. Ser., 125: 21-30.

OUELLET, P., D. LEFAIVRE, and V. KOUTITONSKY. 1990. Distribution of shrimp (Pandalus borealis) larvae and hydrographic pattern in the northern Gulf of St. Lawrence. Can. J. Fish. Aquat. Sci., 47: 20682078.

OUELLET, P., C. T. TAGGART, and K. T. FRANK. 1992. Lipid condition and survival in shrimp (Pandalus borealis) larvae. Can. J. Fish. Aquat. Sci. 49: 368-378.

OUELLET, P., and D. LEFAIVRE. 1994. Vertical distribution of northern shrimp (Pandalus borealis) larvae in the Gulf of St. Lawrence; Implications for trophic interactions and transport. Can. J. Fish. Aquat. Sci., 51: 123-132.

OUELLET, P., C. T. TAGGART, and K. T. FRANK. 1995. Early growth, lipid composition, and survival expectations of shrimp Pandalus borealis larvae in the northern Gulf of St. Lawrence. Mar. Ecol. Prog. Ser., 126: 163-175.

PEDERSEN, S. A., and E. L. B. SMIDT. MS 1995. Zooplankton investigations off West Greenland, 1956-1984. ICES C.M. Doc., No. L:15, 53 p.

PIKE, R. B., and D. I. WILLIAMSON. 1964. The larvae of some species of Pandalidae (Decapoda). Crustaceana, 6: 265-284.

RASMUSSEN, T. MS 1993. Temperature dependent development, growth, and mortality of Northern shrimp larvae (Pandalus borealis KRØYER 1838) in the laboratory. Master of Science thesis (Can. scient.) University of Troms $\varnothing$, Norway. $74 \mathrm{p}+$ appendix. (in Norwegian).

RASMUSSEN, T., and K. TANDE. 1995. Temperaturedependent development, growth and mortality in larvae of the deep-water prawn Pandalus borealis reared in the laboratory. Mar. Ecol. Prog. Ser., 
118: $149-157$.

SHUMWAY, S. E., PERKINS, H. C., SHICK, D. F., and A. P. STICKNEY. 1985. Synopsis of biological data on the pink shrimp, Pandalus borealis Krøyer, 1838. NOAA Tech. Rep. NMFS, 30, (FAO Fisheries Synopsis No. 144). 57 p.

SMIDT, E. L. B. 1979. Annual cycles of primary production and of zooplankton at Southwest Greenland. Meddelelser om Grønland, Bioscience No. 1, 53 p.

SMITH, P. E., and S. L. RICHARDSON. 1977. Standard techniques for pelagic fish egg and larvae surveys. FAO Fish. Tech. Pap., 175. Rome. 100 p.

STEIN, M., and J. LLORET, 1995. Stability of water masses - impact on cod recruitment off West Greenland. Fish. Oceanog. 4(3): 230-237.

STEIN, M., and V. A. BOROVKOV. 1997. Climatic variability of deep waters off Greenland and in the Labrador Sea. NAFO Sci. Coun. Studies, 30: 27-39.

STEPHENSEN, K. 1935. The Godthaab Expedition 1928. Crustacea Decapoda. Meddelelser om Gronland.
Kommissionen for videnskabelige unders $\phi$ gelser $i$ Grфnland, 80(1), 94 p.

STEVENSON, D. K., and F. PIERCE. 1985. Life history characteristics of Pandalus montagui and Dichelopandalus leptocerus in Penobscot Bay, Maine. Fish. Bull., 83(3): 219-233.

ST. JOHN, M. A. and T. LUND 1996. Lipid biomarkers:linking the utilization of frontal plankton biomass to enhanced condition of juvenile North Sea cod. Mar. Ecol. Prog. Ser., 131: 75-85.

SQUIRES, H. J. 1966. Distribution of decapod Crustacea in the northwest Atlantic. Ser. Atlas. Mar. Environ., Am. Geogr. Soc. Folio 12, 4 p.

SQUIRES, H. J. 1993. Decapod crustacean larvae from Ungava Bay. J. North. Atl. Fish. Sci., 15: 157 p.

TANDE, K. S., T. RASMUSSEN, and G. PEDERSEN. 1994. Thermal Increase Enhancement: a possible link between recruitment and climate in high latitude environments. ICES Mar. Sci. Symp., 198: 502-509. 